\title{
Bacillus velezensis YC7010 Enhances Plant Defenses Against Brown Planthopper Through Transcriptomic and Metabolic Changes in Rice
}

\author{
Md. Harun-Or-Rashid ${ }^{1,2}$, Hyun-Jin Kim ${ }^{3}$, Seon-In Yeom ${ }^{4}$, Hyeon-Ah Yu${ }^{5}$, \\ Md. Maniruzzaman Manir ${ }^{6}$, Surk-Sik Moon ${ }^{6}$, Yang Jae Kang ${ }^{1}$ and Young Ryun Chung ${ }^{1 *}$ \\ 1 Division of Applied Life Science (BK21 Plus), Plant Molecular Biology and Biotechnology Research Center, Gyeongsang \\ National University, Jinju, South Korea, ${ }^{2}$ Division of Entomology, Bangladesh Agricultural Research Institute, Rangpur, \\ Bangladesh, ${ }^{3}$ Division of Applied Life Science (BK21 Plus), Department of Food Science and Technology, College \\ of Agriculture and Life Sciences, Gyeongsang National University, Jinju, South Korea, ${ }^{4}$ Department of Agricultural Plant \\ Science, Institute of Agriculture and Life Science, Gyeongsang National University, Jinju, South Korea, ${ }^{5}$ Napro Biotech, \\ Gongju, South Korea, ${ }^{6}$ Department of Chemistry, Kongju National University, Gongju, South Korea
}

\section{OPEN ACCESS}

Edited by:

Michele Perazzolli,

Fondazione Edmund Mach, Italy

Reviewed by:

Rosa Rao,

University of Naples Federico II, Italy

Mario Serrano,

Universidad Nacional Autónoma de México, Mexico

Fei Gao,

University of Missouri, United States

${ }^{*}$ Correspondence: Young Ryun Chung yrchung@gnu.ac.kr

Specialty section:

This article was submitted to Plant Microbe Interactions,

a section of the journal

Frontiers in Plant Science

Received: 07 June 2018 Accepted: 07 December 2018 Published: 21 December 2018

Citation:

Rashid MH, Kim H-J, Yeom S-I, Yu H-A, Manir MM, Moon S-S, Kang YJ and Chung YR (2018)

Bacillus velezensis YC7010 Enhances Plant Defenses Against Brown Planthopper Through Transcriptomic and Metabolic Changes in Rice.

Front. Plant Sci. 9:1904. doi: 10.3389/fp/s.2018.01904
Brown planthopper (BPH; Nilaparvata lugens Stål) is one of the most serious insect pests, which reduce rice yield remarkably in many rice-growing areas. A few plant growth-promoting rhizobacteria induce systemic resistance against herbivorous insects. Here we show that root drenching of rice seedlings with an endophytic strain Bacillus velezensis YC7010 enhanced defenses against BPH. Based on high-throughput transcriptome analysis, systemic resistance against $\mathrm{BPH}$ was induced by $B$. velezensis YC7010 via salicylic acid (SA)- and jasmonic acid (JA)-dependent pathways. Increased leaf contents of secondary metabolites, tricin and C-glycosyl flavone and cell-wall contents of lignin and cellulose were the key defense mechanisms inducing resistance against $\mathrm{BPH}$ during the three-way interaction. This study shows for the first time that chemical changes and strengthening of physical barriers play important roles simultaneously in plant defense against BPH in rice by the endophytic bacteria. This defense was induced by lipopeptides including a novel bacillopeptin $\mathrm{X}$.

Keywords: Bacillus velezensis YC7010, brown planthopper, induce systemic resistance, rice, secondary metabolites

\section{INTRODUCTION}

The brown planthopper (BPH; Nilaparvata lugens Stål) is one of the major damaging insect pests of rice (Oryza sativa L.) with a typical herbivorous phloem-sucking habit. Continued BPH infestations normally reduce photosynthates and thereby hinder plant growth, which causes the wilting of tillers, known as "hopper-burn" and heavy yield losses in susceptible rice varieties (Liu et al., 2008). Their feeding also spreads certain rice viruses such as grassy stunt virus and ragged stunt virus, which are serious problems associated with rice production in cultivated areas of Asia (Suzuki et al., 2015). The main control methods for BPH involve an integrated pest management strategy via application of chemical insecticides and/or cultivation of resistant varieties. However, breakdown of plant resistance to $\mathrm{BPH}$ and $\mathrm{BPH}$ resistance to chemical insecticides often results in increased levels of infestation (Hu et al., 2016). Abuse or misuse of chemicals results in the destruction of the natural 
balance of $\mathrm{BPH}$ predators that control the $\mathrm{BPH}$ population and also cause insect resurgence (Tanaka et al., 2000). During the last decades, development of integrated pest management approaches based on natural resources and traits such as host resistance and biological control was used to reduce the role of chemical pesticides in insect control strategy (Hong-xing et al., 2017). Biological control using microorganisms or antibiotics offers a good alternative to chemical control and provides efficient control with little or no natural environmental hazard (Li et al., 2014). Use of plant growth-promoting rhizobacteria (PGPR) is a potential strategy for successful biological control (Nelson, 2004).

Plant growth-promoting rhizobacteria living in association with the roots of higher plants increase host adaptation under biotic and abiotic stresses to increase their growth and improve stress tolerance (Niazi et al., 2014). PGPR may activate molecular and physiological alterations in plants mediating enhanced plant defense to pathogens as well as insect pests via induced systemic resistance (ISR) (Van Oosten et al., 2008; De Vleesschauwer and Höfte, 2009; Pineda et al., 2010; Rashid et al., 2017). The endophytic bacteria colonize the rhizosphere effectively by competing with the native soil microbiota (Garbeva et al., 2004). Recent studies investigating the enormous diversity and abundance of endophytic bacteria in plants raised interest in the development of endophytic bacteria as biological control agents (D’Alessandro et al., 2014). Plant defense systems also were triggered by bacterial endophytes through a variety of pathways resulting in the alteration of host plant physiology accordingly (Compant et al., 2010; Wielkopolan and ObrêpalskaStêplowska, 2016). The mechanisms of plant defense against plant pathogens induced by rhizobacteria are well investigated, but the mechanisms against herbivorous insects are not yet elucidated (van Loon et al., 1998; De Vleesschauwer and Höfte, 2009; Pineda et al., 2010).

To initiate plant defense mechanisms against herbivorous insects and simultaneously establish associations with PGPR, plants use phytohormones such as ethylene (ET), jasmonic acid (JA), and salicylic acid (SA) as signal molecules to coordinate their immune responses (Pieterse et al., 2012; Zamioudis and Pieterse, 2012). Differences in defense mechanisms were observed depending on the feeding behavior of chewing or sucking insects (Pineda et al., 2010). Sucking insects such as phloem-feeding whiteflies and aphids that cause little injury to plant foliage are perceived as pathogens and primarily activate SA-dependent and to a certain extent JA/ET-dependent signaling pathways to ISR (Walling, 2000; Li et al., 2006; Zarate et al., 2007). JA-mediated defenses are known to be activated against chewing insects (Kessler et al., 2004; De Vos et al., 2005; Zheng et al., 2007; Howe and Jander, 2008; Van Oosten et al., 2008). ISR against whiteflies by Bacillus subtilis strain BEB-DN (BsDN) appear to be a combination of JA-dependent and -independent responses (Valenzuela-Soto et al., 2010).

A wide range of elicitors such as volatile compounds and lipopeptides produced by PGPR are perceived by host plants to activate the ISR in defense responses and the related metabolic changes in plants (Ryu et al., 2004; Ongena et al., 2007; Henry et al., 2011). After early perception of pest infestation in host plants, various defense-related metabolites such as phytoalexin and phenolic compounds are accumulated in association with ISR mechanisms (De Vleesschauwer et al., 2008). The biosynthesis of a wide variety of phenolic compounds including flavonoids occurs via phenylpropanoid pathway in the plant defense against herbivores (McMullen et al., 2009; Rashid and Chung, 2017). In the biosynthesis of phenolics, phenylalanine ammonia-lyase (PAL) is the initial enzyme in the phenylpropanoid pathway inducing plant resistance (Pellegrini et al., 1994; Polle et al., 1994). Oxidative enzymes such as peroxidase (POD) and polyphenol oxidase (PPO) are also important in the formation of other oxidative phenolic compounds and lignin that are associated with defense barriers for strengthening the cell structure against plant pathogens and insects (Avdiushko et al., 1993; McMullen et al., 2009; Cesarino et al., 2012). The increased content of both lignin and cellulose induced by foliar endophytic fungus plays an important role in reduction of damage induced by pathogens and herbivores in a tropical tree, Theobroma cacao (Mejía et al., 2014). In addition to defense-related chemical compounds, plant proteins and lectins are known to exhibit insecticidal activity. Orysata, a jacalin-related lectin from rice protects host plant against both biting-chewing beet armyworm and piercing-sucking aphids (Vandenborre et al., 2011; Al Atalah et al., 2014).

Although $\mathrm{BPH}$ is one of the major insect pests in rice, little is known about the molecular mechanism of interaction with the host and its attack. Yuan et al. (2005) reported the upregulation of macromolecule degradation and plant defense genes, whereas the genes for photosynthesis and cell growth were downregulated by $\mathrm{BPH}$ infestation of the susceptible rice cultivar. OsLOX1, JA biosynthesis gene, induced tolerance of the rice plant to wounding and $\mathrm{BPH}$ attack, and the SA and ET signaling pathways were positively correlated with resistance to $\mathrm{BPH}$ attack in rice (Wang R. et al., 2008; Zhou et al., 2009; Lu et al., 2011). However, genes related to wounding, oxidative and pathogen stresses overlapped extensively between BPH-resistant and susceptible rice lines (Wei et al., 2009). RNA sequencing analysis of rice with $\mathrm{BPH}$ infestation revealed that genes encoding JA/ET signaling, receptor kinase, MAPK cascades, $\mathrm{Ca}^{2+}$ signaling and protein posttranslational modifications play an important role in the defense mechanism ( $\mathrm{Lv}$ et al., 2014). In addition, secondary metabolites including flavonoids, phenylpropanoids, polyphenols, oxalic and silicic acid and phenolics also play essential roles in rice resistance to BPH (Yoshihara et al., 1979, 1980; Stevenson et al., 1996; Zhao et al., 2004; Schwachtje and Baldwin, 2008; Liu et al., 2010). Among these compounds, tricin is one of the flavonoids especially shown to induce resistance against BPH in a resistant rice cultivar (Bing et al., 2007).

In this study, the molecular mechanism and biochemical changes induced by the endophytic strain of B. velezensis YC7010 were elucidated using an integrated analysis of the transcriptome and the metabolome of rice-endophytic bacterial interaction to defense against $\mathrm{BPH}$ in rice. Endophytic stain $B$. velezensis YC7010 was isolated from rice root with plant growth promoting, antibiotic and induced systemic resistance to soil-borne rice bacterial, fungal pathogens, and insect (Chung et al., 2015; Hossain et al., 2016; Rashid et al., 2017). The chemical structure of a novel compound inducing ISR against $\mathrm{BPH}$ was also 
determined. The results provide novel insights into the dynamic molecular changes of the three-way interaction between rice, bacteria and $\mathrm{BPH}$ in terms of defense response against the destructive insect pest.

\section{MATERIALS AND METHODS}

\section{Preparation of Rice Seedlings and Rearing of BPH}

Rice (Oryza sativa L. ssp. japonica cv. Dongjin) seeds were surface-sterilized with $70 \%$ ethanol for $5 \mathrm{~min}$ followed by $1.2 \%$ sodium hypochlorite $(\mathrm{NaOCl})$ solution for $5 \mathrm{~min}$ and rinsed with sterile distilled water several times. The seeds were left in water at $30^{\circ} \mathrm{C}$ for 3 days in dark with daily change of water. The germinated seeds were sown in commercial nursery potting soils and incubated in a growth chamber at $30^{\circ} \mathrm{C}$ (light; $200 \mu \mathrm{mol}$ $\mathrm{m}^{-2} \mathrm{sec}^{-1}$ and $16 \mathrm{~h}$-light/ $8 \mathrm{~h}$-dark regime) (Hossain et al., 2016). The 2 -week-old seedlings were transplanted into the plastic pots $\left(11.5 \mathrm{~cm} \times 10 \mathrm{~cm} \times 7.5 \mathrm{~cm}^{3}\right)$ containing about $150 \mathrm{~g}$ of sterilized nursery soils and cultivated until completion of tests. The $\mathrm{BPH}$ population was collected from the rice paddy fields located at Jinju, Korea. The BPH insects were reared on susceptible rice seedlings Taichung Native-1 (TN1) in the growth chamber at $30^{\circ} \mathrm{C}$ with $80 \%$ relative humidity.

\section{Induction of Systemic Resistance to BPH by $B$. velezensis YC7010}

The endophytic B. velezensis YC7010 isolated from rice root was used to induce systemic resistance against $\mathrm{BPH}$. The bacterial strain was cultivated in one-tenth strength tryptic soy broth (1/10 TSB, Bacto ${ }^{\mathrm{TM}}$, Sparks, MD, United States) on a rotary shaker $(160 \mathrm{rpm})$ at $28^{\circ} \mathrm{C}$ for $48 \mathrm{~h}$. Cells were centrifuged at 6,000 $\mathrm{g}$ for $15 \mathrm{~min}$ and suspended in a buffer solution $\left(10 \mathrm{mM} \mathrm{MgSO}_{4}\right)$ to adjust to $2 \times 10^{7} \mathrm{CFU} \mathrm{ml}^{-1}$ for use (Chung et al., 2015). Threeweek-old rice seedlings were drenched with $15 \mathrm{~mL}$ bacterial suspension on the rhizosphere in each pot. An equal volume of $10 \mathrm{mM} \mathrm{MgSO}_{4}$ was drenched as control. At 5 days after bacterial inoculation, both treated and control plants were infested with $15 \mathrm{~s}$ instar nymphae per plant seedling and covered using fine and light-transmitting mesh. Seven days post-infestation, the $\mathrm{BPH}$ severity score of each seedling was assessed using a score of 0 , 1, 3, 5, 7 or 9 (Huang et al., 2001). Each treatment had fifteen replicates. Experiments were conducted three times.

\section{Plant Materials and RNA Extraction}

Three-week-old rice seedlings were used for RNA extraction after treatment with the bacterial strain and BPH (Supplementary Figure S1). A total of $10 \mathrm{~s}$ instar nymphae were laid on both bacteria-treated and untreated control plants at 5 days after bacterial treatment. The leaves of 15 treated and untreated rice plants were collected as a mixed sample at $48 \mathrm{~h}$ post infestation (hpi) with or without $\mathrm{BPH}$ and $\mathrm{BPH}$ was removed from the leaves before samples collection. Four samples were collected from bacterial untreated without (Control) or with $(\mathrm{Control}+\mathrm{BPH}) \mathrm{BPH}$ and bacterial treated without (YC7010) or with (YC7010 + BPH) BPH infested rice plants. All experiments were conducted in three biological replicates. Collected leaves were frozen and ground in liquid nitrogen to a fine powder and the total RNA was extracted from the samples using RNA extraction kit (Qiagen RNeasy Plant Mini Kit) according to the manufacturer's instructions and the RNA-seq paired end libraries were constructed using three biological replicates at $48 \mathrm{hpt}$ using Illumina TruSeq RNA Sample Preparation Kit v2 (catalog \#RS122-2001, Illumina, San Diego, CA, United States) according to the manufacturer's instructions.

\section{Transcriptome Analysis}

Starting with total RNA, mRNA purified using poly (A) selection or rRNA depleted, then RNA chemically fragmented and converted into single-stranded cDNA using random hexamer priming. Next, the second strand is generated to create doublestranded cDNA. Library construction begins with generation of blunt-end cDNA fragments from ds-cDNA. Then A-base added to the blunt-end in order to make them ready for ligation of sequencing adapters. After the size selection of ligates, the ligated cDNA fragments which contain adapter sequences are enhanced via PCR using adapter specific primers. The library was quantified with KAPA library quantification kit (Kapa Biosystems KK4854) following the manufacturer's instructions. All constructed libraries with an insert length of $101 \mathrm{bp}$ were sequenced using Illumina HiSeq 2000 (Illumina Inc., San Diego, CA, United States; Supplementary Table S1). Sequence data whose quality of bp was higher than $\mathrm{Q} \geq 20$ were extracted by SolexaQA (Cox et al., 2010). Trimmed reads were mapped using the RNA-seq mapping algorithm implemented in bowtie2 (v2.1.0) software (Langmead et al., 2009) to the transcripts of $O$. sativa MSU release 7 from Phytozome V.10 1 (Ouyang et al., 2006) allowing all alignment with a maximum of two mismatches. The number of mapped clean reads for each gene was counted and normalized with DESeq package in $\mathrm{R}$ (Anders and Huber, 2010) to avoid bias due to different sequencing amounts. The RNA-Seq sequences of this test have been deposited at the NCBI and the accession number is SAMN10364481 86 .

\section{Analysis of Differentially Expressed Genes}

Differentially expressed genes (DEGs) were identified by a $\geq 2$-fold change in the number of mapped reads, a binomial test with a false discovery rate $(F D R) \leq 0.01$, and a read count $\geq 1,000$ between samples. The FDR was applied to identify the threshold $p$-value for multiple tests and was calculated using DESeq (Anders and Huber, 2010). All correlation analysis and hierarchical clustering were performed using AMAP library in $\mathrm{R}$ (Lucas, 2014). For pathway analysis, we mapped all DEGs using the MapMan package (Thimm et al., 2004) with the Osa_MSU_v7 mapping file and latest pathways downloaded from the official web site ${ }^{2}$. For each DEG gene list, down-regulated and up-regulated genes were annotated using Gene Ontology (GO)

\footnotetext{
${ }^{1}$ http://phytozome.jgi.doe.gov/pz/portal.html\#!info?alias=Org_Osativa

${ }^{2}$ http://mapman.gabipd.org/web/guest/mapman
} 
based on the similarity of protein sequences in the GO database (Ashburner et al., 2000). The number of genes assigned in each GO term was counted using in-house scripts of SEEDERS Co.

\section{Real-Time qPCR}

Sixteen genes of MapMan pathway classifications were selected for validation using real-time qPCR. Primer sets were designed with the OligoPerfect ${ }^{\mathrm{TM}}$ Designer software and the primers used in real-time qPCR are provided in Supplementary Table S2 as supporting information. Quantitative real-time PCR was performed using the CFX96 ${ }^{\circledR}$ Real-Time PCR Detection System

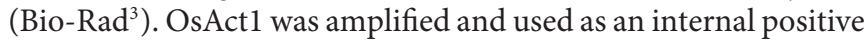
control. All results had three biological replicates.

\section{Assay of Defense-Related Enzyme Activity}

Three defense-related enzymes including PAL, PPO, and POD were measured using 3 -week-old rice seedlings treated with the bacterial strain and BPH. Both treated and untreated control plants were exposed to a total of $10 \mathrm{BPH}$ at 5 days after bacterial treatment. For enzyme assay, the leaves of 15 treated and untreated rice plants were collected as a mixed samples at 0, 24, and 48 hpi of BPH. To measure the activities of PAL (Qin and Tian, 2005), $3 \mathrm{~g}$ of rice samples from each treatment were homogenized with polyvinyl pyrrolidone (PVP) ( $0.5 \mathrm{~g})$ and sodium borate buffer $\left(30 \mathrm{ml}, 50 \mathrm{mmol} \mathrm{L}^{-1}, \mathrm{pH} 8.8\right.$, containing $5 \mathrm{mmol} \mathrm{L}{ }^{-1} \beta$-mercaptoethanol) and crushed by tissue grinder at $4^{\circ} \mathrm{C}$. Grinding samples were centrifuged at $15,000 \times g$ for $30 \mathrm{~min}$ at $4^{\circ} \mathrm{C}$, and the supernatant was collected for PAL assays. Enzyme extract $(1 \mathrm{ml})$ was incubated with borate buffer $(2 \mathrm{ml}$, $\left.50 \mathrm{mmol} \mathrm{L}{ }^{-1}, \mathrm{pH} 8.8\right)$ and L-phenylalanine $(0.5 \mathrm{ml}, 20 \mathrm{mmol}$ $\left.\mathrm{L}^{-1}\right)$ at $37^{\circ} \mathrm{C}$ for $60 \mathrm{~min}$. The reaction was stopped with $\mathrm{HCl}$ $\left(0.1 \mathrm{ml}, 6 \mathrm{~mol} \mathrm{~L}{ }^{-1}\right)$. The PAL activity was determined by the absorbance change at $290 \mathrm{~nm}$. To measure the activities of PPO and POD (Chen et al., 2000), $3 \mathrm{~g}$ of rice samples from each treatment were homogenized with sodium phosphate buffer (30 ml, $0.1 \mathrm{~mol} \mathrm{~L}^{-1}, \mathrm{pH}$ 6.4) and PVP (0.5 g) and ground at $4^{\circ} \mathrm{C}$. The mixture were centrifuged at $15,000 \times g$ for $30 \mathrm{~min}$ at $4^{\circ} \mathrm{C}$, and the supernatant were used for PPO and POD assays. The PPO activity were determined by adding $1 \mathrm{ml}$ of enzyme preparation to $2 \mathrm{ml}$ of catechol as a substrate, and the change were measured immediately in absorbance at $398 \mathrm{~nm}$ (A398). The POD activity was measured by guaiacol as a substrate. The reaction mixture contained of crude extract $(2 \mathrm{ml})$, buffer $(1 \mathrm{ml})$, and guaiacol $(1 \mathrm{ml})$. The reaction mixture was incubated for $30 \mathrm{~min}$ at $30^{\circ} \mathrm{C}$ before added of $\mathrm{H}_{2} \mathrm{O}_{2}(1 \mathrm{ml})$. Absorbance was calculated at $460 \mathrm{~nm}$ (A460). All results had three biological replicates.

\section{Measurement of Chlorophyll, Lignin and Cellulose Content}

To measure chlorophyll, lignin and cellulose contents in leaves or stem, rice seedlings were collected at $5 \mathrm{~d}$ after $\mathrm{BPH}$ infestation from 15 bacteria-treated and untreated plants and the contents

${ }^{3} \mathrm{http}: / /$ www.bio-rad.com/ were determined. The total chlorophyll content was determined as described previously (Rashid et al., 2017). Lignin was measured quantitatively according to Lange et al. (1995). Extraction of cell wall materials and determination of cellulose contents were conducted as described previously (Updegraff, 1969; Li et al., 2003). All results had three biological replicates.

\section{Metabolomics Analysis and Data Processing}

A metabolomics analysis of rice interaction with $\mathrm{BPH}$ and bacteria was conducted by collecting the leaves of 3-week-old rice seedlings with or without $\mathrm{BPH}$ at $48 \mathrm{~h}$ after bacterial infection. The samples were collected from 15 rice plants for each treatment. The collected samples were homogenized with $80 \%$ aqueous methanol with terfenadine as an internal standard using a bullet blender (Next Advance, NY, United States) to extract metabolites. After centrifugation, the extracted metabolites in supernatants were analyzed using an ultra-performance liquid chromatography-quadrupole/time-of-flight mass spectrometry (UPLC-Q-TOF MS) system (Xevo ${ }^{\mathrm{TM}}$ G2-S; Waters, Milford, MA, United States). The samples were injected into an Acquity UPLC BEH C18 column $(2.1 \mathrm{~mm} \times 100 \mathrm{~mm}, 1.7 \mu \mathrm{m}$; Waters $)$ at a column temperature of $40^{\circ} \mathrm{C}$. The mobile phase consisted of water with $0.1 \%$ formic acid in water (A) and $\mathrm{ACN}$ with $0.1 \%$ formic acid (B) at a flow rate of $0.35 \mathrm{~mL} / \mathrm{min}$ for $15 \mathrm{~min}$. The eluents were analyzed using a Q-TOF MS with positive electrospray ionization (ESI). The scan range of TOF MS data was 100 to $1500 \mathrm{~m} / \mathrm{z}$ with a scan time of $0.2 \mathrm{~s}$. The capillary and sampling cone voltages were set at $3 \mathrm{kV}$ and $40 \mathrm{~V}$, respectively. The desolvation flow rate was $900 \mathrm{~L} / \mathrm{h}$ at a temperature of $300^{\circ} \mathrm{C}$ and source temperature set to $100^{\circ} \mathrm{C}$. Leucine-enkephalin $([\mathrm{M}+\mathrm{H}]=556.2771)$ was used as a reference compound for lack mass at a frequency of $10 \mathrm{~s}$. Quality control (QC) samples prepared by mixing equal amounts of samples were injected periodically. The MS/MS spectra were collected in the $\mathrm{m} / \mathrm{z}$ 50-1500 using a collision energy ramp from 10 to $45 \mathrm{eV}$. All MS data, including retention time, $\mathrm{m} / z$, and ion intensity, obtained by UPLC-Q-TOF MS, were extracted with MarkerLynx software (Waters) for data processing. The peaks were collected using peak-to-peak baseline noise of 1 , noise elimination of 6 , a peakwidth at $5 \%$ height of $1 \mathrm{~s}$ and an intensity threshold of 10,000. The metabolite data were evenly arranged with a mass window $(0.05 \mathrm{Da})$ and a retention time window $(0.2 \mathrm{~min})$. All data was normalized to the internal standard. Identification of the metabolites was based on Unifi software (Waters) with various online databases.

\section{Structure Determination of Bacterial Compounds With ISR Activity to BPH General Experimental Procedures}

The NMR spectra were recorded on a Varian Mercury 400 spectrometer (Varian Inc) with standard pulse sequences operating at $400 \mathrm{MHz}$ for ${ }^{1} \mathrm{H}-\mathrm{NMR}$ and $100 \mathrm{MHz}$ for ${ }^{13} \mathrm{C}-\mathrm{NMR}$. Chemical shifts, measured in ppm, were referenced to solvent peaks $\left(\delta_{\mathrm{H}} 2.50\right.$ and $\delta_{\mathrm{C}} 39.5$ for DMSO- $\left.d_{6}\right)$. HR-TOF-MS spectra were recorded in the positive ESI mode on a Waters Synapt G2 at 
A

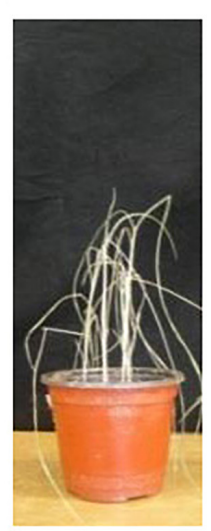

Control

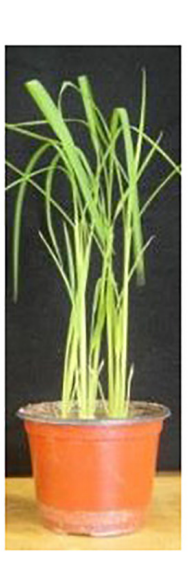

YC7010
B

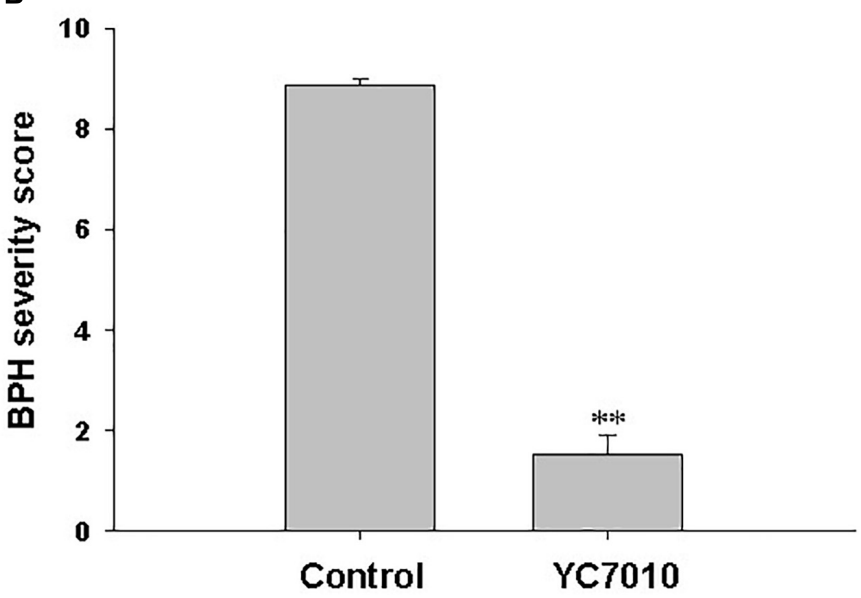

FIGURE 1 | Induction of systemic resistance to BPH in rice by inoculation of Bacillus velezensis YC7010. Bacterial suspension $\left(2 \times 10^{7} \mathrm{CFU} / \mathrm{mL}\right)$ was drenched to the rhizosphere of 3-week-old rice seedlings while $10 \mathrm{mM} \mathrm{MgSO}_{4}$ solution was used as negative control. Five days later, plants were infested with $15 \mathrm{~s}$ instar nymphae per plant seedling and covered using a fine, light-transmitting mesh. (A) Rice seedlings imaged after BPH infestation. (B) BPH severity score was determined at 7 days after infestation. Data were analyzed by independent Student's $t$-tests. Bars represent mean values \pm standard error (SE). Statistical significance for treatment effects is marked ${ }^{* *} P<0.01$. Each treatment had fifteen replicates. All experiments were conducted in triplicate with similar results.

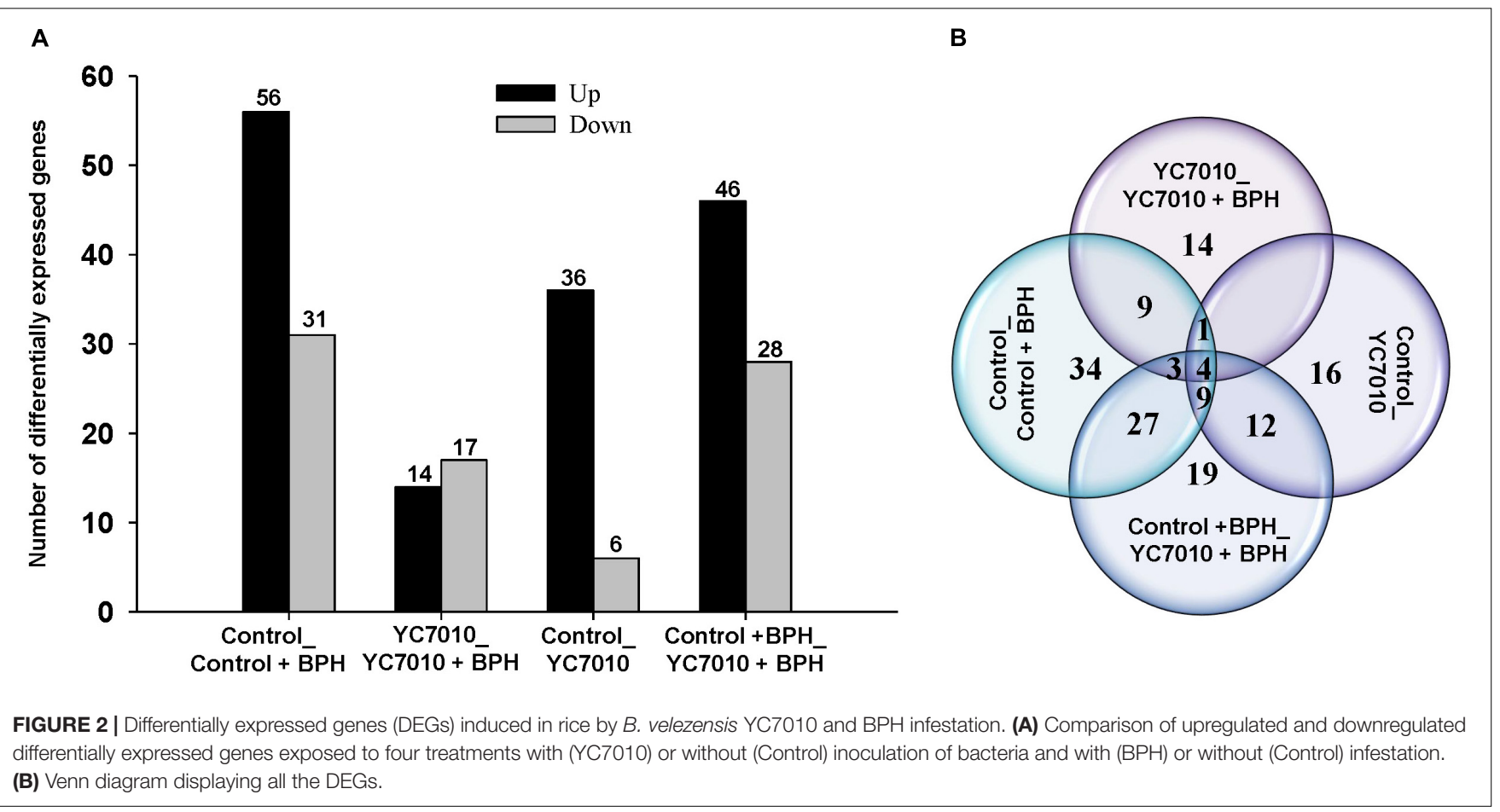

the Korea Basic Science Institute. Flash column chromatography was performed on a C18 silica gel column (Cosmosil 75C18Prep, Nacalai Tesque, Koyoto, Japan; $100 \mathrm{id} \times 180 \mathrm{~mm}$ ) using a $10 \%$ stepwise gradient elution of increasing $\mathrm{MeOH}$ concentration in $\mathrm{H}_{2} \mathrm{O}$ (2.0 L each). Medium pressure liquid chromatography (MPLC) was carried out using silica gel column (230-400 mesh, 25 id $\times 110 \mathrm{~mm}$ ) with a Yamazen pump 540 eluting with a EtOAC-MeOH gradient (1:0, 1:1, and 0:1, $500 \mathrm{~mL}$ each). Preparative C18 HPLC was conducted on a Gilson 321 pump equipped with a photodiode array UV detector UV/VIS-151 using Varian Dynamax HPLC column $(21.4$ id $\times 250 \mathrm{~mm}$, Microsorb 100-5 $\mu \mathrm{m} \mathrm{C18,} \mathrm{90-100 \%} \mathrm{aqueous} \mathrm{MeOH}$ ) utilized UV detection of peaks at $220 \mathrm{~nm}$, flow rate of eluent at $7 \mathrm{~mL} / \mathrm{min}$, and gradient elution for $80 \mathrm{~min}$.

Extraction and isolation of bacterial compounds are detailed in the Supplementary Table S3. To determine the ISR activity of the active compound to $\mathrm{BPH}$, surface-sterilized seeds with $70 \%$ ethanol for $5 \mathrm{~min}$ followed by $1.2 \%$ sodium hypochlorite 
$(\mathrm{NaOCl})$ solution for $5 \mathrm{~min}$ and rinsed with sterile distilled water several times were sown on microwell plates $(2 \mathrm{~cm} \times 2 \mathrm{~cm})$ containing half-strength MS solid media with $0.8 \%(\mathrm{w} / \mathrm{v})$ agar. The seeds were cultivated for 2 weeks in a growth chamber under the same conditions as described in the preparation of rice seedlings. The roots of seedlings were treated with $100 \mu \mathrm{l}$ solution of purified compound (bacillopeptin A, bacillopeptin B and bacillopeptin $\mathrm{X} ; 100 \mu \mathrm{g} \mathrm{ml}^{-1}$ ) dissolved in distilled water and an equal volume of water was used to drench the roots as control. Five days after chemical treatment, the treated seedlings were transplanted into pots $(11.5 \mathrm{~cm} \times 10 \mathrm{~cm} \times 7.5 \mathrm{~cm})$ containing about $150 \mathrm{~g}$ of sterilized nursery soils and infested with 15 second instar nymphae per seedling at 3 days after transplant. Seven days after BPH infestation, the severity score was assessed as described previously. Each treatment had fives replicates. Experiments were conducted three times.

\section{Statistical Analysis}

All data were subjected to the analysis of variance (ANOVA) technique and the mean differences were estimated by Tukey's HSD and Student's $t$-test using statistical software, SPSS 17 (SPSS Inc. Chicago) and Sigma plot (version 12).

\section{RESULTS}

\section{Induction of Systemic Resistance to BPH by $B$. velezensis YC7010}

The endophytic strain B. velezensis YC7010 was tested for its capacity to trigger ISR to $\mathrm{BPH}$ in rice. Seven days after infestation with $15 \mathrm{~s}$ instar nymphaea, the rice seedlings root-drenched with the bacterial suspension were healthy, whereas untreated control plants showed symptoms of severe stem chlorosis, leaf wilting and even death of the whole plant (Figure 1A). Bacteria-treated plants exhibited a significantly $(P<0.01)$ lower $\mathrm{BPH}$ severity score 1.53 compared with that of untreated control 8.87 (Figure 1B). The results showed that rice seedlings treated with $B$. velezensis YC7010 induced resistance against infestation by BPH.

\section{Transcriptome Analysis of Rice Treated With B. velezensis YC7010 in Response to BPH Infestation}

Gene expression profiles of rice seedlings treated and untreated with bacteria were investigated using deep RNA sequencing to identify defense-related genes in rice in response to $\mathrm{BPH}$ infestation to elucidate the molecular mechanism of systemic resistance induced by $B$. velezensis YC7010. RNAs extracted from rice samples at $48 \mathrm{hpi}$ of $\mathrm{BPH}$ in inoculated and untreated control plants were sequenced and DEGs of samples were analyzed. In the study, we defined DEGs as the transcripts showing at least a twofold change of the FPKM (fragments per kilo base of exon per million fragments mapped) (log2FC $\geq 1$ or $\log 2 \mathrm{FC} \leq-1$ ) and a $P$-value $<0.01$. In total, $134 \mathrm{DEGs}$ were detected by comparing the four treatments with (YC7010) or without (Control) inoculation of bacteria and with $(\mathrm{BPH})$ or without (Control) infestation of insects (Supplementary
Table S4). BPH infestation altered the gene expression of the untreated plant significantly, including upregulation of 56 genes and downregulation of 31 genes (Control_Control + $\mathrm{BPH}$ ). After root drenching of rice seedlings with the bacteria, there were 42 differentially expressed genes, including 36 upregulated genes and 6 downregulated genes compared with the untreated control. Following bacterial treatment of rice roots, BPH infestation showed fewer DEGs than in other comparisons (YC7010_YC7010 + BPH). There were 31 DEGs, including 14 upregulated genes and 17 downregulated genes. Comparison of DEGs between bacteria-treated and untreated plants infested with BPH (Control + BPH_YC7010 + BPH) revealed significant changes in gene expression of the infected plants, including 46 upregulated genes and 28 downregulated genes (Figure 2A). Moreover, the number of DEGs between Control_Control + BPH and YC7010_YC7010 + BPH, YC7 010_YC7010 + BPH and Control_YC7010, Control_YC7010 and Control + BPH_YC7010 + BPH and Control_Control + BPH and Control + BPH_YC7010 + BPH were $17(9+1+4+3)$, $5(1+4), 25(12+9+4)$, and $43(4+9+27+3)$, respectively (Figure 2B).

Differentially expressed genes were imported into the MapMan software and the classification based on the hierarchical functional categories, BINs and sub-BINs is listed in Supplementary Table S5 and provided in Supplementary Figure S2. The overview analysis using the MapMan software grouped 125 DEGs into 25 BINs. This global overview suggested that about $74.4 \%$ of 93 genes grouped into MapMan BINs were classified under 9 major functional classes with 5 or more genes. The BIN 1 representing 'Photosynthesis' group comprised the most number of DEGs (24) (Supplementary Figure S2). Based on the MapMan software and GO function pathway analyses, we identified several genes related to major pathways such as early defense signaling, oxidative stress, photosynthesis, carbohydrate, secondary metabolites and cellwall modification were investigated in detail to understand the defense mechanisms and the functional significance underlying the three-way interaction (Figure 3 and Supplementary Table S6).

\section{Early Defense Signaling Induced by $B$. velezensis YC7010 and BPH Infestation in Rice}

Six genes were involved in perception and signal transduction pathways in which $\mathrm{Ca}^{2+}$ played an important role as a second messenger. These included LRR family protein receptors such as protein kinase EXS precursor (LOC_Os02g40240.1), receptor-like protein kinase 5 (LOC_Os02g13510.1) and brassinosteroid-insensitive 1-associated receptor kinase 1 precursor BAK1 (LOC_Os11g39370.1). The three genes were upregulated in both bacteria-inoculated and control plants after $\mathrm{BPH}$ infestation, but were downregulated in $\mathrm{BPH}$-infested plants treated with bacteria compared with the untreated $\mathrm{BPH}$ infested plant (Figure 3). $\mathrm{Ca}^{2+}$ signaling-related genes such as calmodulin binding protein (LOC_Os12g36110.1) and calmodulin-dependent protein kinases (LOC_Os04g49510.1) 


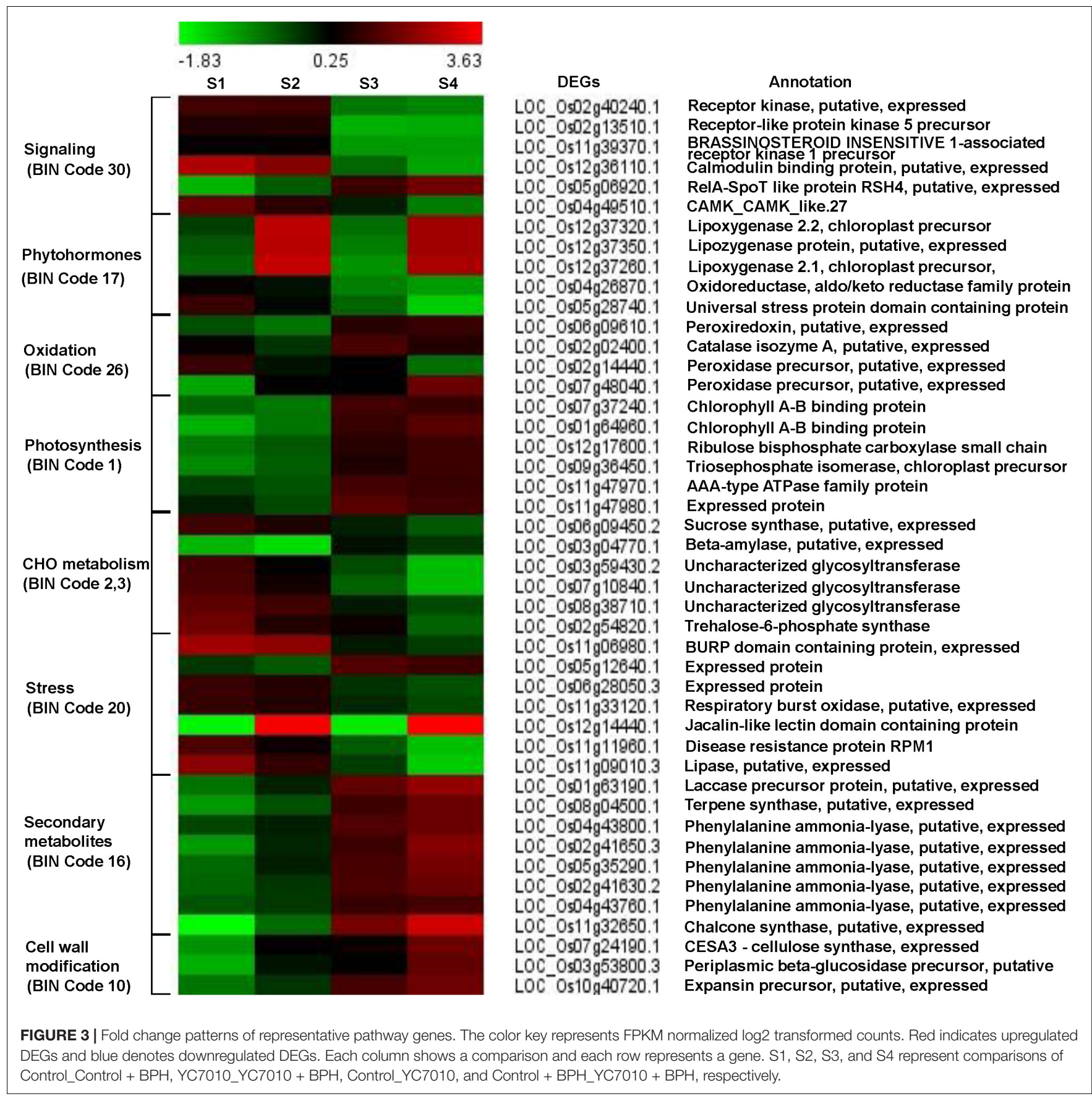

were upregulated in both inoculated and control plants after $\mathrm{BPH}$ infestation. The relA-SpoT like protein $\mathrm{RSH} 4$ (LOC_Os05g06920.1) was down-regulated in both treated and control plants after BPH infestation; however, it was upregulated in BPH-infested plants exposed to bacteria compared with $\mathrm{BPH}$-infested plants unexposed to bacteria (Figure 3).

Following bacterial treatment and $\mathrm{BPH}$ infestation, JA, ET and auxin-related genes were differentially expressed in the signaling pathway (Figure 3). Three genes controlling JA synthesis including lipoxygenase 2.2 (LOC_Os12g37320.1), lipoxygenase protein (LOC_Os12g37350.1) and lipoxygenase 2.1
(LOC_Os12g37260.1) were remarkably upregulated by bacterial treatment in plants infested with $\mathrm{BPH}$.

\section{Oxidative Stress Response to $B$. velezensis YC7010 and $\mathrm{BPH}$ Infestation in Rice}

Three oxidative stress-related genes including a peroxiredoxin (LOC_Os06g09610.1), a catalase (LOC_Os02g02400.1) and a peroxidase (LOC_Os07g48040.1) were upregulated in response to bacterial treatment of $\mathrm{BPH}$-infested plants compared with 


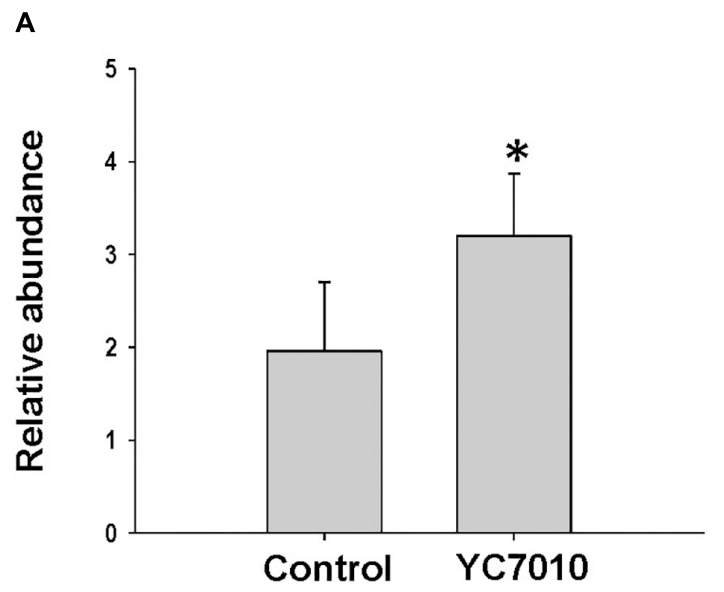

C

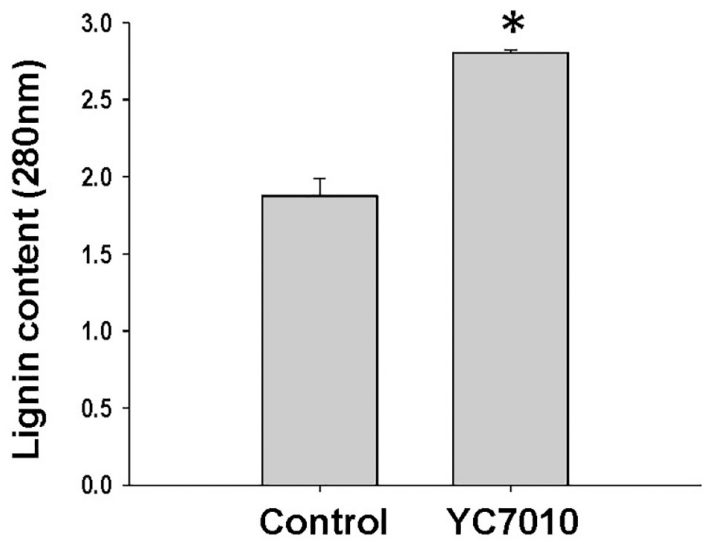

B

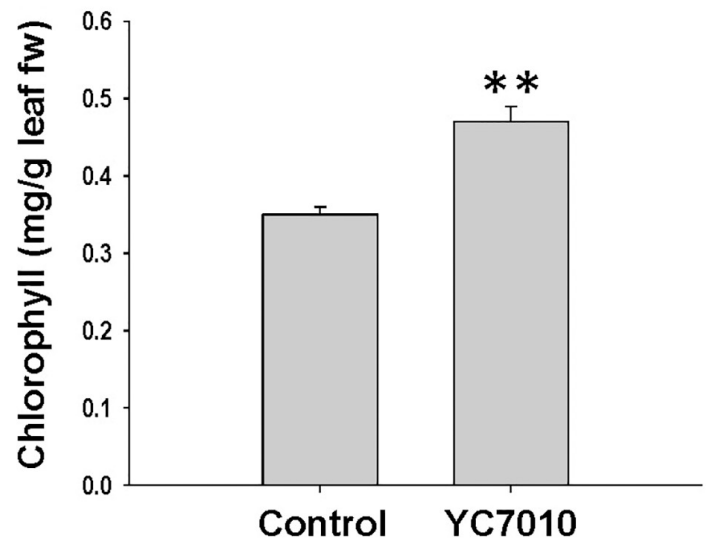

D

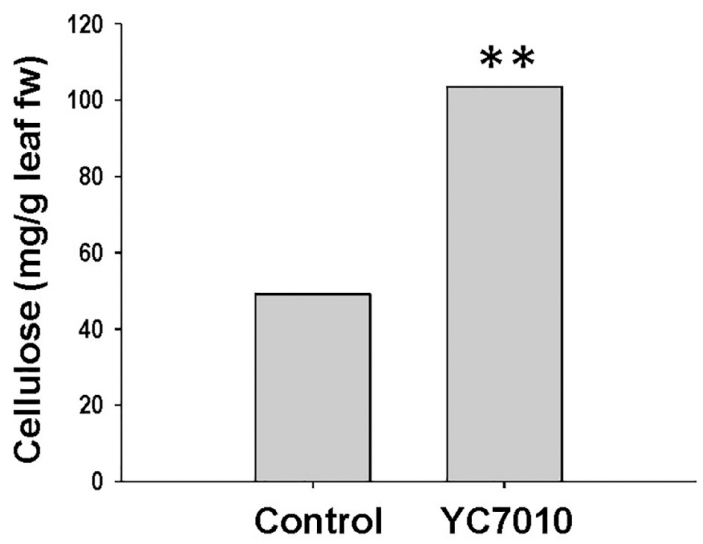

FIGURE 4 | Measurement of (A) chlorophyll derivative; (B) chlorophyll; (C) lignin; and (D) cellulose content in rice plants treated with B. velezensis YC7010. Bacterial suspension $\left(2 \times 10^{7} \mathrm{CFU} / \mathrm{mL}\right.$ ) was drenched to the rhizosphere of 3-week-old rice plants. A total of $10 \mathrm{~s}$ instar nymphae per plant seedling were used at 5 days after treatment. Chlorophyll derivatives were measured at $48 \mathrm{hpi}$. Chlorophyll, lignin and cellulose contents were measured at 5 days after infestation. The samples were collected from 15 bacteria treated and untreated plants. All experiments were conducted three times. Data were analyzed by independent Student's $t$-tests. Bars represent mean values \pm standard error (SE). Statistical significance for treatment effects is marked $* P<0.05, * * P<0.01$.

BPH-infested plants without bacterial inoculation (Figure 3). However, another peroxidase gene (LOC_Os02g14440.1) was downregulated. Even with the inoculation of only bacteria, all these genes were upregulated without infestation of $\mathrm{BPH}$.

\section{Photosynthesis and Carbohydrate Metabolism Changes by $B$. velezensis YC7010 and BPH Infestation in Rice}

The functional category of photosynthesis presents the highest number of DEGs (Supplementary Figure S2). Most of the DEGs assigned to photosynthesis were upregulated by bacterial treatment regardless of $\mathrm{BPH}$ infestation and were downregulated by BPH infestation (Figure 3), which was confirmed by metabolomics analysis. The relative abundance of chlorophyll derivatives and chlorophyll content was higher in treated plants than in untreated plants after $\mathrm{BPH}$ infestation (Supplementary Figure S3 and Figures 3, 4A,B). The carbohydrate $(\mathrm{CHO})$ metabolism was also affected by the inoculation of YC7010 and BPH infestation. DEGs related to $\mathrm{CHO}$ metabolism such as a sucrose synthase (LOC_Os06g09450.2), a beta-amylase (LOC_Os03g04770.1), and three uncharacterized glycosyltransferases (LOC_Os03g59430.2, LOC_Os07g10840.1 and LOC_Os08g38710.1) and a trehalose-6-phosphate synthase (LOC_Os02g54820.1) were downregulated following $\mathrm{BPH}$-infestation of treated plants compared with plants without bacterial inoculation (Figure 3).

\section{Metabolites and Cell Wall Modification Induced by B. velezensis YC7010 and BPH Infestation}

The colonization of rice roots by YC7010 resulted in enhanced expression of terpene and chalcone synthase genes (LOC_Os08g04500.1 and LOC_Os11g32650.1). Transcriptome analysis showed that flavonoids such as tricin and $C$-glycosyl flavone biosynthesis genes were upregulated following BPH infestation in bacteria-treated rice (Figure 5A). Metabolome analysis further confirmed a higher tricin content 


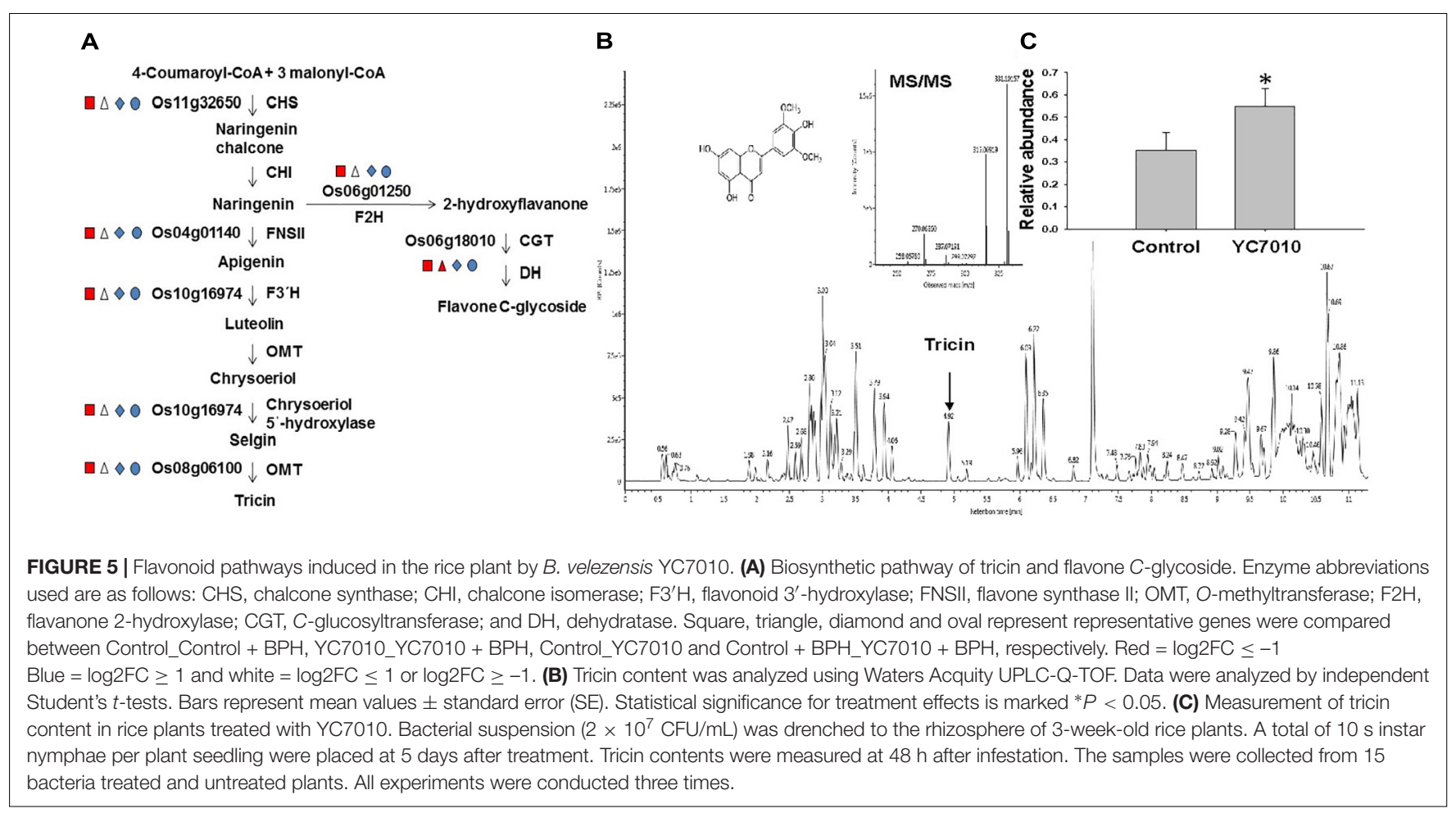

in infected plants compared with uninfected control plants (Figures 5B,C). This study also showed that the activities of PAL, PPO, and POD were significantly higher in bacteriatreated rice than in untreated control plants at $48 \mathrm{hpi}$ of $\mathrm{BPH}$ (Figures 6A-C). The accumulation of lignin was significantly higher in bacteria treated plants than untreated plants after BPH infestation (Figure 4C). Root drenching with YC7010 enhanced the expression of a cellulose synthesis gene (LOC_Os07g24190.1), which increased the cellulose content (Figures 3, 4D).

\section{qRT-PCR Analysis of Differentially Expressed Genes}

To validate the changes observed in the RNA sequencing data, qRT-PCR analysis of 16 representative genes showed differential expression following the interaction between plants, microbes and insects (Supplementary Figure S4). The pairwise relative expression differences comparing bacteriatreated and untreated control plants were considered for the elucidation of the defense responses induced at $48 \mathrm{hpi}$ of $\mathrm{BPH}$. The qRT-PCR data of these genes were consistent with the RNA sequencing results. Especially, both qRT-PCR and RNA sequencing analyses showed that genes related to jasmonate metabolism (LOC_Os12g37320.1, LOC_Os12g37350.1 and LOC_Os12g37260.1), secondary metabolism (LOC_Os01g63190.1, LOC_Os08g04500.1, LOC_Os04g43800.1, LOC_Os02g41650.3, LOC_Os05g35290.1, LOC_Os02g41630.2, LOC_Os04g43760.1 and LOC_Os11g32650.1), stress (LOC_Os12g14440.1) and photosynthesis (LOC_Os09g36450.1) were up-regulated in plants infected with bacteria compared with control plants after BPH infestation. Similarly, the expression patterns of two oxidation-related genes (LOC_Os02g02400.1 and LOC_Os07g48040.1), and genes involved in cell-wall modification (LOC_Os07g24190.1) in the infected and control plants after $\mathrm{BPH}$ infestation were found similar in RNA sequencing and qRT-PCR analyses.

\section{Isolation and Identification of Compounds With Elicitation of ISR to BPH}

To determine the chemical structure of compounds to elicit ISR to BPH by YC7010, active compounds were isolated and purified from the culture broth of YC7010. The methanol extract of bacterial culture broth was subjected to multiple chromatographic purification steps including reversed-phase $\mathrm{C} 18$ flash column chromatography, silica MPLC, and preparative C18 HPLC to produce three lipopeptides: one new (3) and two known bacillopeptins (1-2) (Figure 7A).

Compounds 1-3 were obtained as pale brown solids. The molecular formulae of 1-3 were determined to be $\mathrm{C}_{46} \mathrm{H}_{72} \mathrm{~N}_{10} \mathrm{O}_{16}$, $\mathrm{C}_{47} \mathrm{H}_{74} \mathrm{~N}_{10} \mathrm{O}_{16}$, and $\mathrm{C}_{48} \mathrm{H}_{76} \mathrm{~N}_{10} \mathrm{O}_{16}$, respectively, based on their HR-TOF-MS (m/z 1043.5016 [M + Na ${ }^{+}, 1057.5172$ $[\mathrm{M}+\mathrm{Na}]^{+}$, and $1071.5360[\mathrm{M}+\mathrm{Na}]^{+}$respectively, positive ESI mode) measurements and confirmed by ${ }^{13} \mathrm{C}$ NMR data (Supplementary Figures S5-S13). Compounds 1 and 2 were identified by comparison of their spectroscopic data and physical properties with those reported in the literature, as bacillopeptin A and bacillopeptin B (Kajimura et al., 1995), respectively. 


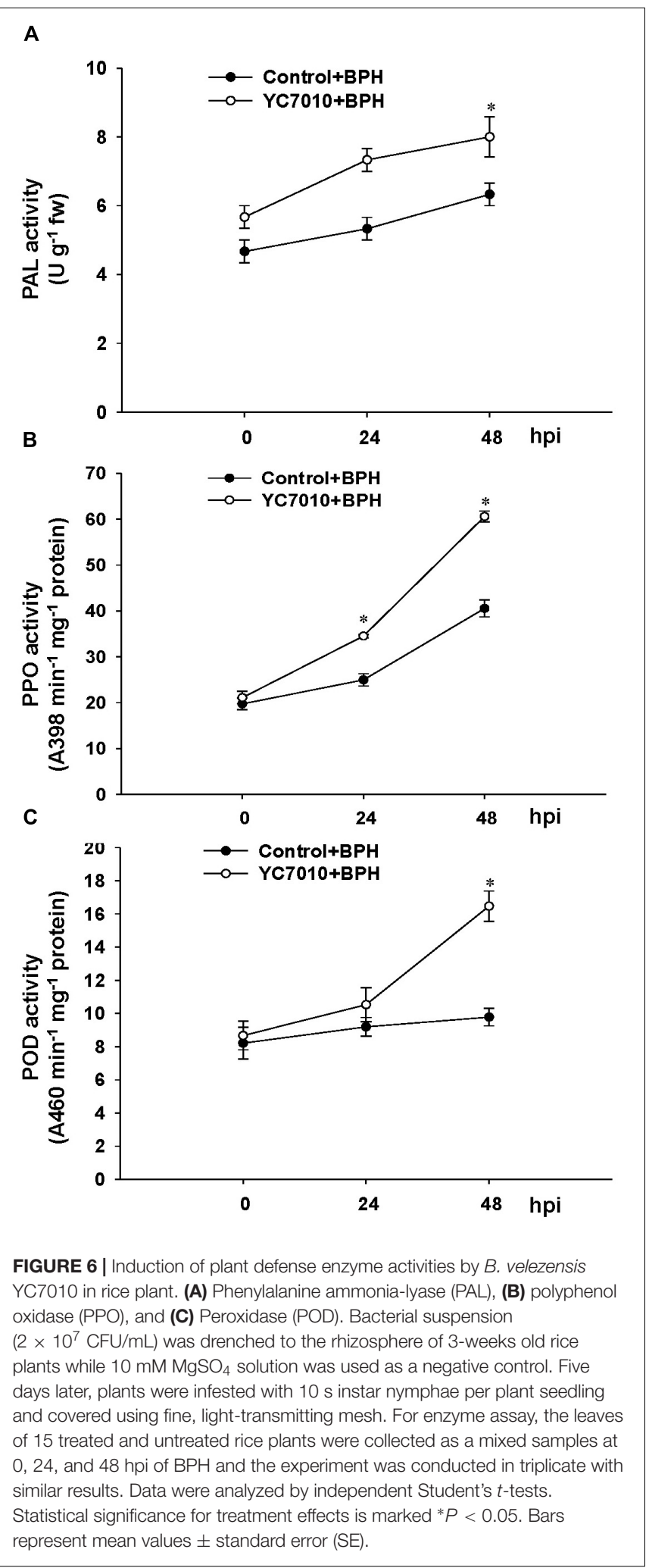

The molecular formula $\mathrm{C}_{48} \mathrm{H}_{76} \mathrm{~N}_{10} \mathrm{O}_{16}$ of compound 3, deduced from its HR-TOF-MS, was 28 mass units higher than that of the compound 1 , and 14 mass units higher than that of the compound 2. Detailed NMR spectroscopic analyses indicated that compounds 1-3 contained identical amino acid sequence and skeleton, but structurally different only in the $\beta$-amino acid side chain. The length and type of $\beta$-amino acid chains were determined by a combination of the molecular weight and chemical shift of the terminal methyl group. The ${ }^{1} \mathrm{H}$ and ${ }^{13} \mathrm{C}$ NMR spectra of 1-3 showed the presence of the $-\left(\mathrm{CH}_{2}\right)_{10} \mathrm{CH}_{3}$,$\left(\mathrm{CH}_{2}\right)_{9} \mathrm{CH}\left(\mathrm{CH}_{3}\right)_{2}$, and $-\left(\mathrm{CH}_{2}\right)_{12} \mathrm{CH}_{3}$ groups, respectively. Thus, the structure of 3 was identified as a novel compound with a $\beta$-amino acid chain length of 16 carbons.

To 7 days after infestation with $15 \mathrm{~s}$ instar nymphae per plant seedling, control and bacillopeptin A treated plants showed symptoms of stem chlorosis, leaf wilting and even death of the whole plant, whereas plants treated with bacillopeptin $\mathrm{B}$ and bacillopeptin $\mathrm{X}$ were healthy (Figure 7B). Bacillopeptin X-treated plants were healthier with a severity score of 3.4 compared with bacillopeptin B-treated plants with 4.2. However, bacillopeptin B and bacillopeptin X-treated plants exhibited a significant reduction in $\mathrm{BPH}$ infestation compared with bacillopeptin $\mathrm{A}$ and untreated control (Figure 7C). The results indicated that bacillopeptin $\mathrm{B}$ and bacillopeptin $\mathrm{X}$ might induce systemic resistance to $\mathrm{BPH}$.

\section{DISCUSSION}

Systemic resistance induced in plant by certain beneficial PGPR or endophytic bacteria commonly found inside roots against insect pests (Pineda et al., 2010; Van de Mortel et al., 2012; de Oliveira Araujo, 2015). These bacteria with ability to enhance plant growth and development have the potential to be utilized for biological control of numerous insect pests. We have previously identified an endophytic B. velezensis YC7010 with anti-microbial, plant growth-promoting, and systemic resistance-inducing activity against insect (Chung et al., 2015; Hossain et al., 2016; Rashid et al., 2017). In this study, our results demonstrated that root drenching of rice with B. velezensis YC7010 suspension resulted in the establishment of an ISR against $\mathrm{BPH}$ (Figure 1). Valenzuela-Soto et al. (2010) reported that inoculation of tomato roots with growth-promoting $B$. subtilis retarded the development of phloem-feeding insect whitefly by inducing resistance, which is in agreement with our results. However, few reports have been published to date on tritrophic interactions among bacteria, insects and host plants, which were inadequate to elucidate the mechanism of ISR against insects by endophytic bacteria.

RNA sequencing of the bacterial treated and the untreated rice plants provided transcriptome data on the mechanism of resistance conferred by $B$. velezensis YC7010. In our study, several rice genes have been associated with the $\mathrm{BPH}$ and bacterial interaction for the first time, which provides information on signal transduction pathways and defense responses elicited by the $\mathrm{BPH}$ in rice. We analyzed plants at $48 \mathrm{hpi}$, before the development of visible symptoms, 


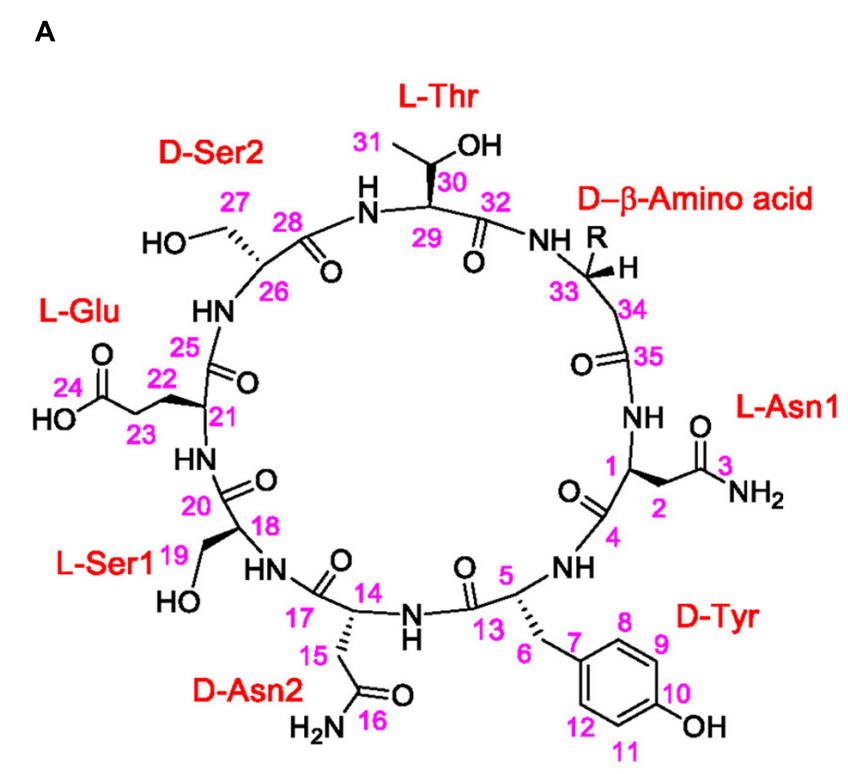

B

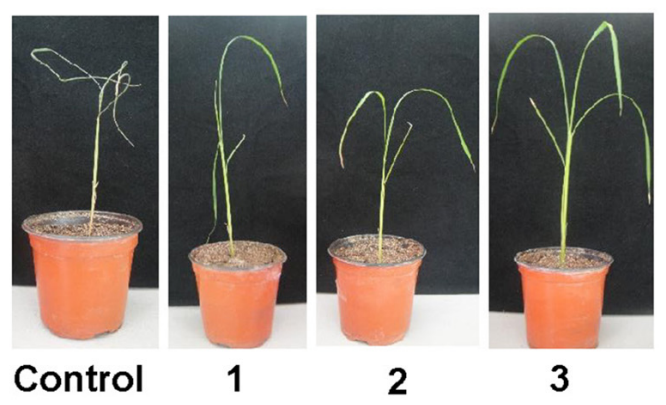

C

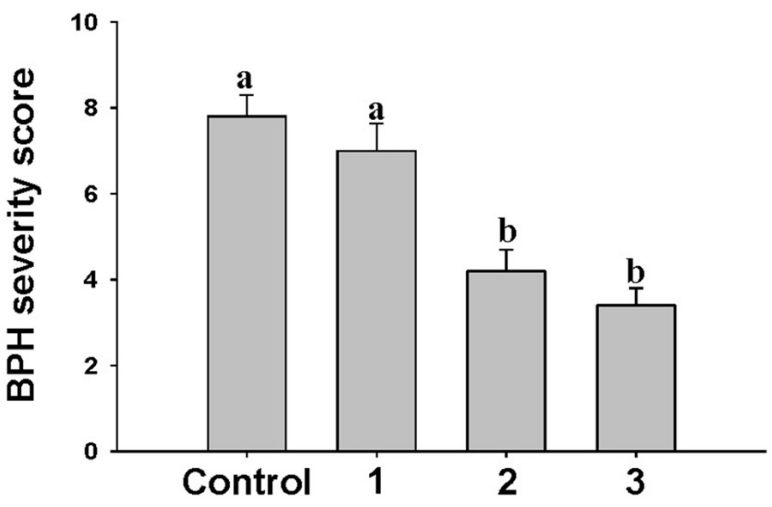

FIGURE 7 | Chemical structure of compounds with ISR activity to BPH isolated from culture broth of B. velezensis YC7010. (A) Structures of the isolates from B. velezensis YC7010. Sterilized seeds were sown on the microwell plates $\left(2 \mathrm{~cm} \times 2 \mathrm{~cm} /\right.$ whole) cultivated at growth chamber at $30^{\circ} \mathrm{C}$ (light; $200 \mu \mathrm{mol} \mathrm{m}^{-2} \mathrm{sec}^{-1}$ and $16 \mathrm{~h}$-light/8 h-dark regime). Two-weeks old rice seedlings were treated with $100 \mu \mathrm{l}$ of bacillopeptin A (1), bacillopeptin B (2) and bacillopeptin X (3) and water was drenched as control. Seedlings were transplanted to plastic pots containing $150 \mathrm{~g}$ soil 5 days after treatment. Plants were infested with $15 \mathrm{~s}$ instar nymphae per plant seedling and covered using fine and light-transmitting mesh at 3 days after transplant. (B) Rice seedlings imaged after BPH infestation. (C) BPH severity score was determined at 7 days after infestation. Data were analyzed by one-way ANOVA. Bars represent mean values \pm standard error (SE). Means with different letters were significantly different $(P<0.05)$. Each treatment had fives replicates. Experiments were conducted three times.

and identified the transcript profiles change in different rice samples (Figure 2 and Supplementary Table S4). In our study, LRR family and $\mathrm{Ca}^{2+}$ signaling genes were upregulated in both bacterial treated and control infested plants compared with uninfested plants (Figure 3). The LRR family protein kinases have been implicated to trigger plant defense responses to herbivore attack (Howe and Jander, 2008). The receptor kinases activate downstream signals by inducing the production of reactive oxygen species (ROS) (Wrzaczek et al., 2010). RelA/SpoT stress proteins regulate the expression of chloroplast gene in response to plant defense signals (Givens et al., 2004). In this study, $\mathrm{Ca}^{2+}$ signaling, relA-SpoT like protein $\mathrm{RSH} 4$ was up-regulated with the $\mathrm{BPH}$ infestation in bacteria treated plants compared to control plants, which suggests that the rice defense response to $\mathrm{BPH}$ involved $\mathrm{Ca}^{2+}$ influx.

The initial step in JA biosynthesis generating 12-oxophytodienoic acid (OPDA) from $\alpha$-linolenic acid ( $\alpha$-LeA) is mediated by lipoxygenase $(L O X)$ genes and is involved in the induction of defense responses against wounding and in regulation of the defense gene expression (Stintzi et al., 2001; Wasternack, 2007). Our study identified three lipoxygenase genes, which were upregulated with the $\mathrm{BPH}$ infestation in bacteria treated plants compared to control plants (Figure 3). We suggest that bacterial treatment with YC7010 might enhance effective defense response against $\mathrm{BPH}$ in rice plants wounded by $\mathrm{BPH}$ infestation that might induce biosynthesis of OPDA. Oxidative stress is a general plant reaction to tissue penetration and injury by phloemsap sucking insects (Kehr, 2006). Proteins and metabolites with redox and anti-oxidative properties are, therefore, essential not only for the maintenance of physiological function during their long lifetime but also for the management of phloemsap sucking insect infestations. ROS play several crucial physiological roles within plants at low concentrations. However, their effects become detrimental at higher concentrations (Walz et al., 2002; Kehr, 2006). This study showed BPH feeding induces a strong accumulation of ROS scavengers and enzymatic antioxidant systems in bacterial treated than in control rice plant. The accumulation of ROS scavengers allows resistant plants to avoid detrimental effects, suggesting that the bacterial treatment with $\mathrm{BPH}$ infestation alters the redox status contributing to resistance mechanisms in rice.

Following $\mathrm{BPH}$ infestation of rice leaves, photosynthetic genes were downregulated (Yuan et al., 2005). Several photosynthesis genes were downregulated in both bacteria 
inoculated and control plants following $\mathrm{BPH}$ infestation but those were up-regulated in $\mathrm{BPH}$ infested bacteria treated plants compared to $\mathrm{BPH}$ infested control plants and chlorophyll derivative as well as chlorophyll content was also higher in bacterial treated than in control plants after BPH infestation, suggesting that the rice photosynthetic apparatus was less damaged during $\mathrm{BPH}$ infestation in bacterial treated than in control plant (Figures 3, 4A,B). It was also reported that colonization of tomato roots by growth-promoting rhizobacteria induces resistance against the phloem-feeding insect whitefly via increased expression of photosynthetic genes, consistent with our results (Valenzuela-Soto et al., 2010). The expression of sucrose synthase and beta-amylase expression were downregulated with the $\mathrm{BPH}$ infestation in bacteria treated compared to control plants (Figure 3). It was shown that ingestion of a large amount of phloem sap by continuous feeding of $\mathrm{BPH}$ resulted in a rapid decline in sucrose content triggering the expression of plant genes such as $\alpha$-amylase, which catalyzes the conversion of starch to sucrose. This process maintains normal growth of $\mathrm{BPH}$ in susceptible rice until the storage starch is exhausted (Yuan et al., 2005; Hao et al., 2008). Continuous feeding by $\mathrm{BPH}$ induces inhibition of photosynthesis and reduces the production and translocation of assimilates (Yuan et al., 2005; Wang Y. et al., 2008). Our results suggested that bacterial treatment with YC7010 ensures minimal disruption of the translocation system resulting in reduced loss of sucrose compared with untreated controls. Thus, rice is more resistant to, or tolerant of, the ingestion process by $\mathrm{BPH}$.

The ISR produced during the bacterial and $\mathrm{BPH}$ interaction could have benefited from the up regulated expression of a jacalin-related lectin gene which was used as a control agent against both biting-chewing and piercing-sucking pest insects (Al Atalah et al., 2014) (Figure 3). Jasmonate-regulated proteins (JRPs) such as lipoxygenase and a jacalin-related lectin are associated with numerous biological activities and biochemical processes. These include plant secondary metabolism, formation of cell wall structure, stress adaptation and resistance to pathogens and insects (Pauwels et al., 2009; Tong et al., 2012). The colonization of rice roots by YC7010 resulted in enhanced expression of terpene and chalcone synthase genes (LOC_Os08g04500.1 and LOC_Os11g32650.1) which is known to be associated with the defense against $\mathrm{BPH}$ (Kamolsukyunyong et al., 2013). The expression of PAL genes and phenol synthesis genes, which act as antifeedants against insect herbivores such as Operophtera brumata (L.) in Salix leaves was enhanced by bacterial treatment (Simmonds, 2003) (Figure 3). RNA sequencing analysis showed that flavonoids such tricin and $\mathrm{C}$-glycosyl flavone biosynthesis genes were upregulated with the BPH infestation in bacteria treated compared to control plants (Figure 5). The high C-glycosyl flavones-producing genes in sweet corn protected ears against fall armyworm and Euxesta stigmatias damage (Nuessly et al., 2007). Tricin was shown to confer resistance against $\mathrm{BPH}$ in rice and has been recently reported as the initial step in lignification of monocots (Bing et al., 2007; Lan et al., 2015). In addition, fortification of the cell-wall in bacteria-treated plants was further promoted by the enhanced expression of the SA synthesis-related gene PAL. PAL is involved in the biosynthesis of lignins and plays a considerable role in resistance to small brown planthopper (SBPH) (Pellegrini et al., 1994; Polle et al., 1994; Duan et al., 2014). However, our study also showed the activity of PAL, PPO, and POD were higher in bacterial treated plants than in control plants after BPH infestation (Figure 6). POD and PPO are also known to be involved in the synthesis of lignin and other oxidative phenols that contribute to the formation of defense barriers for reinforced cell structure (Avdiushko et al., 1993) consistent with the increased level of accumulated lignin in bacterial-treated plants (Figure 4C). It has been reported that the changes of peroxidase biosynthesis and cellulose synthase strengthened the physical barriers of rice, which increased resistance against SBPH and rice strive virus (RSV) (Zheng et al., 2013). The upregulation of beta-glucosidase gene (LOC_Os03g53800.3) in bacterial treated plant activates defense responses against both sucking and chewing insects (Wang X. et al., 2005) (Figure 3). Fatty-acid chain lengths of $\mathrm{n}-\mathrm{C} 14$, iso-C15, iso-C16, and $\mathrm{n}-\mathrm{C} 15$ of bacillopeptins $\mathrm{A}$ (compound 1), B (compound 2), $\mathrm{C}$, and $\mathrm{B}_{1}$, respectively, were previously reported from B. subtilis FR-2 (Kajimura et al., 1995) and Bacillus amyloliquefaciens SH-B74 (Ma et al., 2014). However, the compound 3 with fatty-acid chain length of $\mathrm{n}$-C16 was isolated from a new strain of B. velezensis YC7010 (Figure 7). The nature of the $\beta$-amino fatty acid residue indicated that compound 3 was a novel metabolite belonging to the bacillopeptin family and designated as bacillopeptin X. Another endophytic bacterium B. amyloliquefaciens also elicited ISR in plants against fall armyworms by producing lipopeptides (Li et al., 2015). Many Bacillus species are well known to produce a variety of lipopeptides such as iturin, surfactin, and fengycin. Genomic analysis and biosynthesis of these peptides have been reported (Ongena and Jacques, 2008). However, no genetic study of these bacillopeptins has been reported yet. It is necessary to further elucidate the underlying mechanisms to develop them as potential tools for biocontrol of insect pests.

In summary, the root treatment with B. velezensis YC7010 activated ISR against BPH in rice by producing cyclic lipopeptides including a new bacillopeptin $\mathrm{X}$. The results indicate that the key defense mechanism in bacteria-treated rice plants was dependent on SA and JA pathways. Especially, the chemical change in flavonoids, tricin and physical strengthening of cell walls via increased cellulose and lignin contents may play a critical role comprehensively in ISR to BPH. Further analysis showed that hypersensitive reaction (HR) may not be the mechanism underlying the resistance to $\mathrm{BPH}$ in plants infected with bacteria, which resulted in an increase in peroxidase expression and downregulation of LRR receptorlike protein kinase. To the best of our knowledge, this is the first report elucidating the mechanism of ISR against $\mathrm{BPH}$ by an endophytic PGPR. In this aspect, the results of this study facilitate the development of biological control strategies against insect pests using beneficial endophytic bacteria. 


\section{AUTHOR CONTRIBUTIONS}

YC, MR, H-JK, S-IY, S-SM, and YK planned and designed the study. MR, H-AY, H-JK, and MM performed the study. MR, MM, and YK analyzed the data. YC, MR, S-IY, S-SM, and YK wrote the manuscript.

\section{FUNDING}

This work was supported by the "Cooperative Research Program for Agriculture Science \& Technology Development

\section{REFERENCES}

Al Atalah, B., Smagghe, G., and Van Damme, E. J. (2014). Orysata, a jacalin-related lectin from rice, could protect plants against biting-chewing and piercingsucking insects. Plant Sci. 221, 21-28. doi: 10.1016/j.plantsci.2014.01.010

Anders, S., and Huber, W. (2010). Differential expression analysis for sequence count data. Genome Biol. 11, 106-117. doi: 10.1186/gb-2010-11-10-r106

Ashburner, M., Ball, C. A., Blake, J. A., Botstein, D., Butler, H., Cherry, J. M., et al. (2000). Gene ontology: tool for the unification of biology. Nat. Genet. 25, 25-29. doi: 10.1038/75556

Avdiushko, S. A., Ye, X. S., and Kuc, J. (1993). Detection of several enzymatic activities in leaf prints of cucumber plants. Physiol. Mol. Plant Pathol. 42, 441-454. doi: 10.1006/pmpp.1993.1033

Bing, L., Hongxia, D., Maoxin, Z., Di, X., and Jingshu, W. (2007). Potential resistance of tricin in rice against brown planthopper Nilaparvata lugens (Stål). Acta Ecol. Sin. 27, 1300-1306. doi: 10.1016/S1872-2032(07)60 031-6

Cesarino, I., Araújo, P., Domingues Júnior, A. P., and Mazzafera, P. (2012). An overview of lignin metabolism and its effect on biomass recalcitrance. Braz. J. Bot. 35, 303-311. doi: 10.1016/j.biotechadv.2012.03.003

Chen, C., Belanger, R. R., Benhamou, N., and Paulitz, T. C. (2000). Defense enzymes induced in cucumber roots by treatment with plant growth-promoting rhizobacteria (PGPR) and Pythium aphanidermatum. Physiol. Mol. Plant Pathol. 56, 13-23. doi: 10.1006/pmpp.1999.0243

Chung, E. J., Hossain, M. T., Khan, A., Kim, K. H., Jeon, C. O., and Chung, Y. R. (2015). Bacillus oryzicola sp. nov., an endophytic bacterium isolated from the roots of rice with antimicrobial, plant growth promoting, and systemic resistance inducing activities in rice. Plant Pathol. J. 31, 1-13. doi: 10.5423/PPJ. OA.12.2014.0136

Compant, S., Clement, C., and Sessitsch, A. (2010). Plant growth-promoting bacteria in the rhizo- and endosphere of plants: their role, colonization, mechanisms involved and prospects for utilization. Soil Biol. Biochem. 42, 669-678. doi: 10.1016/j.soilbio.2009.11.024

Cox, M. P., Peterson, D. A., and Biggs, P. J. (2010). SolexaQA: at-a-glance quality assessment of Illumina second-generation sequencing data. BMC Bioinformatics 11:485. doi: 10.1186/1471-2105-11-485

D’Alessandro, M. A., Erb, M., Ton, J., Brandenburg, A., Karlen, D., Zopfi, J., et al. (2014). Volatiles produced by soil-borne endophytic bacteria increase plant pathogen resistance and affect tritrophic interactions. Plant Cell Environ. 37, 813-826. doi: 10.1111/pce.12220

de Oliveira Araujo, E. (2015). Rizobacteria in the control of pest insects in agriculture. Afr. J. Plant Sci. 9, 368-373. doi: 10.5897/AJPS2015.1318

De Vleesschauwer, D., Djavaheri, M., Bakker, P. A., and Höfte, M. (2008). Pseudomonas fluorescens WCS374r-induced systemic resistance in rice against Magnaporthe oryzae is based on pseudobactin-mediated priming for a salicylic acid-repressible multifaceted defense response. Plant Physiol. 148, 1996-2012. doi: $10.1104 / \mathrm{pp} .108 .127878$

De Vleesschauwer, D., and Höfte, M. (2009). Rhizobacteria-induced systemic resistance. Adv. Bot. Res. 51, 223-281. doi: 10.1016/S0065-2296(09)51 006-3

De Vos, M., Van Oosten, V. R., Van Poecke, R. M., Van Pelt, J. A., Pozo, M. J., Mueller, M. J., et al. (2005). Signal signature and transcriptome changes of
(PJ01104901)" funded by Rural Development Administration, South Korea. MR was supported by a scholarship from the BK21 Plus Program, the Ministry of Education, South Korea.

\section{SUPPLEMENTARY MATERIAL}

The Supplementary Material for this article can be found online at: https://www.frontiersin.org/articles/10.3389/fpls.2018.01904/ full\#supplementary-material

Arabidopsis during pathogen and insect attack. Mol. Plant Microbe Interact. 18, 923-937. doi: 10.1094/MPMI-18-0923

Duan, C., Yu, J., Bai, J., Zhu, Z., and Wang, X. (2014). Induced defense responses in rice plants against small brown planthopper infestation. Crop J. 2, 55-62. doi: $10.3389 /$ fpls.2017.01744

Garbeva, P., van Veen, J. A., and van Elsas, J. D. (2004). Microbial diversity in soil: selection of microbial populations by plant and soil type and implications for disease suppressiveness. Annu. Rev. Phytopathol. 42, 243-270. doi: 10.1146/ annurev.phyto.42.012604.135455

Givens, R. M., Lin, M. H., Taylor, D. J., Mechold, U., Berry, J. O., and Hernandez, V. J. (2004). Inducible expression, enzymatic activity, and origin of higher plant homologues of bacterial RelA/SpoT stress proteins in Nicotiana tabacum. J. Biol. Chem. 279, 7495-7504. doi: 10.1074/jbc.M311573200

Hao, P., Liu, C., Wang, Y., Chen, R., Tang, M., Du, B., et al. (2008). Herbivoreinduced callose deposition on the sieve plates of rice: an important mechanism for host resistance. Plant Physiol. 146, 1810-1820. doi: 10.1104/pp.107.111484 doi: 10.1104/pp.107.111484

Henry, G., Deleu, M., Jourdan, E., Thonart, P., and Ongena, M. (2011). The bacterial lipopeptide surfactin targets the lipid fraction of the plant plasma membrane to trigger immune-related defence responses. Cell. Microbiol. 13, 1824-1837. doi: 10.1111/j.1462-5822.2011.01664.x

Hong-xing, X. U., Ya-jun, Y., Yan-hui, L. U., Xu-song, Z., Jun-ce, T., Feng-xiang, L., et al. (2017). Sustainable management of rice insect pests by non-chemicalinsecticide technologies in China. Rice Sci. 24, 61-72. doi: 10.1016/j.rsci.2017. 01.001

Hossain, M. T., Khan, A., Chung, E. J., Rashid, M. H., and Chung, Y. R. (2016). Biological control of rice bakanae by an endophytic Bacillus oryzicola YC7007. Plant Pathol. J. 32, 228-241. doi: 10.5423/PPJ.OA.10.2015.0218

Howe, G. A., and Jander, G. (2008). Plant immunity to insect herbivores. Annu. Rev. Plant Biol. 59, 41-66. doi: 10.1146/annurev.arplant.59.032607.092825

$\mathrm{Hu}$, J., Xiao, C., and He, Y. (2016). Recent progress on the genetics and molecular breeding of brown planthopper resistance in rice. Rice 9, 30-41. doi: 10.1186/s12284-016-0099-0

Huang, Z., He, G. C., Shu, L. H., Li, X. H., and Zhang, Q. F. (2001). Identification and mapping of two brown planthopper resistance genes in rice. Theor. Appl. Genet. 102, 929-934. doi: 10.1007/s001220000455

Kajimura, Y., Sugiyama, M., and Kaneda, M. (1995). Bacillopeptins, new cyclic lipopeptide antibiotics from Bacillus subtilis FR-2. J. Antibiot. 48, 1095-1103. doi: 10.7164/antibiotics.48.1095

Kamolsukyunyong, W., Sukhaket, W., Ruanjaichon, V., Toojinda, T., and Vanavichit, A. (2013). Single-feature polymorphism mapping of isogenic rice lines identifies the influence of terpene synthase on brown planthopper feeding preferences. Rice 6, 18-26. doi: 10.1186/1939-8433-6-18

Kehr, J. (2006). Phloem sap proteins: their identities and potential roles in the interaction between plants and phloem-feeding insects. J. Exp. Bot. 57, 767-774. doi: 10.1093/jxb/erj087

Kessler, A., Halitschke, R., and Baldwin, I. T. (2004). Silencing the jasmonate cascade: induced plant defenses and insect populations. Science 305, 665-668. doi: 10.1126/science.1096931

Lan, W., Lu, F., Regner, M., Zhu, Y., Rencoret, J., Ralph, S. A., et al. (2015). Tricin, a flavonoid monomer in monocot lignification. Plant Physiol. 167, 1284-1295. doi: $10.1104 /$ pp.114.253757 
Lange, B. M., Lapierre, C., and Sandermann, H. Jr. (1995). Elicitor-induced spruce stress lignin (structural similarity to early developmental lignins). Plant Physiol. 108, 1277-1287. doi: 10.1104/pp.108.3.1277

Langmead, B., Trapnell, C., Pop, M., and Salzberg, S. L. (2009). Ultrafast and memory-efficient alignment of short DNA sequences to the human genome. Genome Biol. 10:R25. doi: 10.1186/gb-2009-10-3-r25

Li, H., Soares, M. A., Torres, M. S., Bergen, M., and White, J. F. Jr. (2015). Endophytic bacterium, Bacillus amyloliquefaciens, enhances ornamental hosta resistance to diseases and insect pests. J. Plant Interact. 10, 224-229. doi: 10. 1080/17429145.2015.1056261

Li, M., Li, S., Xu, A., Lin, H., Chen, D., and Wang, H. (2014). Selection of Beauveria isolates pathogenic to adults of Nilaparvata lugens. J. Insect Sci. 14:32. doi: $10.1093 /$ jis/14.1.32

Li, Q., Xie, Q. G., Smith-Becker, J., Navarre, D. A., and Kaloshian, I. (2006). Mi-1-mediated aphid resistance involves salicylic acid and mitogen-activated protein kinase signaling cascades. Mol. Plant Microbe Interact. 19, 655-664. doi: 10.1094/MPMI-19-0655

Li, Y., Qian, Q., Zhou, Y., Yan, M., Sun, L., Zhang, M., et al. (2003). BRITTLE CULM1, which encodes a COBRA-like protein, affects the mechanical properties of rice plants. Plant Cell 15, 2020-2031. doi: 10.1105/tpc.011775

Liu, C., Hao, F., Hu, J., Zhang, W., Wan, L., Zhu, L., et al. (2010). Revealing different systems responses to brown planthopper infestation for pest susceptible and resistant rice plants with the combined metabonomic and gene-expression analysis. J. Proteome Res. 9, 6774-6785. doi: 10.1021/pr100970q

Liu, J. L., Yu, J. F., Wu, J. C., Yin, J. L., and Gu, H. N. (2008). Physiological responses to Nilaparvata lugens in susceptible and resistant rice varieties: allocation of assimilates between shoots and roots. J. Econ. Entomol. 101, 384-390. doi: 10.1093/jee/101.2.384

Lu, J., Ju, H., Zhou, G., Zhu, C., Erb, M., Wang, X., et al. (2011). An EARmotif-containing ERF transcription factor affects herbivore-induced signaling, defense and resistance in rice. Plant J. 68, 583-596. doi: 10.1111/j.1365-313X. 2011.04709.x

Lucas, A. (2014). amap: Another Multidimensional Analysis Package. $R$ package version 0.8-12. Available at: http://CRAN.R-project.org/package=amap

Lv, W., Du, B., Shangguan, X., Zhao, Y., Pan, Y., Zhu, L., et al. (2014). BAC and RNA sequencing reveal the brown planthopper resistance gene BPH15 in a recombination cold spot that mediates a unique defense mechanism. $B M C$ Genomics 15:674. doi: 10.1186/1471-2164-15-674

Ma, Z., Hu, J., Wang, X., and Wang, S. (2014). NMR spectroscopic and MS/MS spectrometric characterization of a new lipopeptide antibiotic bacillopeptin B1 produced by a marine sediment derived Bacillus amyloliquefaciens SH-B74. J. Antibiot. 67, 175-178. doi: 10.1038/ja.2013.89

McMullen, M. D., Frey, M., and Degenhardt, J. (2009). "Genetics and biochemistry of insect resistance in maize," in Handbook of Maize: Its Biology, eds J. L. Bennetzen and S. C. Hake (New York, NY: Springer), 271-289. doi: 10.1007/ 978-0-387-79418-1_14

Mejía, L. C., Herre, E. A., Sparks, J. P., Winter, K., García, M. N., Van Bael, S. A., et al. (2014). Pervasive effects of a dominant foliar endophytic fungus on host genetic and phenotypic expression in a tropical tree. Front. Microbiol. 5:479. doi: $10.3389 /$ fmicb.2014.00479

Nelson, L. M. (2004). Plant growth promoting rhizobacteria (PGPR): prospects for new inoculants. Crop Manag. 10, 301-305. doi: 10.1094/CM-2004-0301-05-RV

Niazi, A., Manzoor, S., Asari, S., Bejai, S., Meijer, J., and Bongcam-Rudloff, E. (2014). Genome analysis of Bacillus amyloliquefaciens subsp. plantarum UCMB5113: a rhizobacterium that improves plant growth and stress management. PLoS One 9:e104651. doi: 10.1371/journal.pone.0104651

Nuessly, G. S., Scully, B. T., Hentz, M. G., Beiriger, R., Snook, M. E., and Widstrom, N. W. (2007). Resistance to Spodoptera frugiperda (Lepidoptera: Noctuidae) and Euxesta stigmatias (Diptera: Ulidiidae) in sweet corn derived from exogenous and endogenous genetic systems. J. Econ. Entomol. 100, 1887-1895. doi: 10. 1093/jee/100.6.1887

Ongena, M., and Jacques, P. (2008). Bacillus lipopeptides: versatile weapons for plant disease biocontrol. Trends Microbiol. 16, 115-125. doi: 10.1016/j.tim.2007. 12.009

Ongena, M., Jourdan, E., Adam, A., Paquot, M., Brans, A., Joris, B., et al. (2007). Surfactin and fengycin lipopeptides of Bacillus subtilis as elicitors of induced systemic resistance in plants. Environ. Microbiol. 9, 1084-1090. doi: 10.1111/j. 1462-2920.2006.01202.x
Ouyang, S., Zhu, W., Hamilton, J., Lin, H., Campbell, M., Childs, K., et al. (2006). The TIGR rice genome annotation resource: improvements and new features. Nucleic Acids Res. 35, 883-887. doi: 10.1093/nar/gkl976

Pauwels, L., Inzé, D., and Goossens, A. (2009). Jasmonate-inducible gene: what does it mean? Trends Plant Sci. 14, 87-91. doi: 10.1016/j.tplants.2008.11.005

Pellegrini, L., Rohfritsch, O., Fritig, B., and Legrand, M. (1994). Phenylalanine ammonia-lyase in tobacco (molecular cloning and gene expression during the hypersensitive reaction to tobacco mosaic virus and the response to a fungal elicitor). Plant Physiol. 106, 877-886. doi: 10.1104/pp.106.3.877

Pieterse, C. M. J., Van der Does, D., Zamioudis, C., Leon-Reyes, A., and Van Wees, S. C. (2012). Hormonal modulation of plant immunity. Annu. Rev. Cell Dev. Biol. 28, 489-521. doi: 10.1146/annurev-cellbio-092910-154055

Pineda, A., Zheng, S. J., VanLoon, J. J. A., Pieterse, C. M. J., and Dicke, M. (2010). Helping plants to deal with insects: the role of beneficial soil-borne microbes. Trends Plant Sci. 15, 507-514. doi: 10.1016/j.tplants.2010.05.007

Polle, A., Otter, T., and Seifert, F. (1994). Apoplastic peroxidases and lignification in needles of Norway spruce (Picea abies L.). Plant Physiol. 106, 53-60. doi: 10.1104/pp.106.1.53

Qin, G. Z., and Tian, S. P. (2005). Enhancement of biocontrol activity of Cryptococcus laurentii by silicon and the possible mechanisms involved. Phytopathology 95, 69-75. doi: 10.1094/PHYTO-95-0069

Rashid, M. H., and Chung, Y. R. (2017). Induction of systemic resistance against insect herbivores in plants by beneficial soil microbes. Front. Plant Sci. 8:1816. doi: 10.3389/fpls.2017.01816

Rashid, M. H., Khan, A., Hossain, M. T., and Chung, Y. R. (2017). Induction of systemic resistance against aphids by endophytic Bacillus velezensis YC7010 via expressing PHYTOALEXIN DEFICIENT4 in Arabidopsis. Front. Plant Sci. 8:211. doi: 10.3389/fpls.2017.00211

Ryu, C. M., Farag, M. A., Hu, C. H., Reddy, M. S., Kloepper, J. W., and Paré, P. W. (2004). Bacterial volatiles induce systemic resistance in Arabidopsis. Plant Physiol. 134, 1017-1026. doi: 10.1104/pp.103.026583

Schwachtje, J., and Baldwin, I. T. (2008). Why does herbivore attack reconfigure primary metabolism? Plant Physiol. 146, 845-851. doi: 10.1104/pp.107.112490

Simmonds, M. S. (2003). Flavonoid-insect interactions: recent advances in our knowledge. Phytochemistry 64, 21-30. doi: 10.1016/S0031-9422(03)00293-0

Stevenson, P. C., Kimmins, F. M., Grayer, R. J., and Raveendranath, S. (1996). Schaftosides from rice phloem as feeding inhibitors and resistance factors to brown planthoppers, Nilaparvata lugens. Entomol. Exp. Appl. 80, 246-249. doi: 10.1111/j.1570-7458.1996.tb00928.x

Stintzi, A., Weber, H., Reymond, P., and Farmer, E. E. (2001). Plant defense in the absence of jasmonic acid: the role of cyclopentenones. Proc. Natl. Acad. Sci. U.S.A. 98, 12837-12842. doi: 10.1073/pnas.211311098

Suzuki, N., Sasaya, T., and Choi, I. R. (2015). Viruses threatening stable production of cereal crops. Front. Microbiol. 6:470. doi: $10.3389 /$ fmicb. 2015.00470

Tanaka, K., Endo, S., and Kazano, H. (2000). Toxicity of insecticides to predators of rice planthoppers: spiders, the mirid bug and the dryinid wasp. Appl. Entomol. Zool. 35, 177-187. doi: 10.1303/aez.2000.177

Thimm, O., Bläsing, O., Gibon, Y., Nagel, A., Meyer, S., Krüger, P., et al. (2004). Mapman: a user-driven tool to display genomics data sets onto diagrams of metabolic pathways and other biological processes. Plant J. 37, 914-939. doi: 10.1111/j.1365-313X.2004.02016.x

Tong, X., Qi, J., Zhu, X., Mao, B., Zeng, L., Wang, B., et al. (2012). The rice hydroperoxide lyase OsHPL3 functions in defense responses by modulating the oxylipin pathway. Plant J. 71, 763-775. doi: 10.1111/j.1365-313X.2012.05027.x

Updegraff, D. M. (1969). Semimicro determination of cellulose in biological materials. Anal. Biochem. 32, 420-424. doi: 10.1016/S0003-2697(69)80009-6

Valenzuela-Soto, J. H., Estrada-Hernández, M. G., Ibarra-Laclette, E., and DélanoFrier, J. P. (2010). Inoculation of tomato plants (Solanum lycopersicum) with growth-promoting Bacillus subtilis retards whitefly Bemisia tabaci development. Planta 231, 397-410. doi: 10.1007/s00425-009-1061-9

Van de Mortel, J. E., de Vos, R. C., Dekkers, E., Pineda, A., Guillod, L., Bouwmeester, K., et al. (2012). Metabolic and transcriptomic changes induced in Arabidopsis by the rhizobacterium Pseudomonas fluorescens SS101. Plant Physiol. 160, 2173-2188. doi: 10.1104/pp.112.207324

van Loon, L. C., Bakker, P. A., and Pieterse, C. M. (1998). Systemic resistance induced by rhizosphere bacteria. Annu. Rev. Phytopathol. 36, 453-483. doi: 10.1146/annurev.phyto.36.1.453 
Van Oosten, V. R., Bodenhausen, N., Reymond, P., Van Pelt, J. A., Van Loon, L. C., Dicke, M., et al. (2008). Differential effectiveness of microbially induced resistance against herbivorous insects in Arabidopsis. Mol. Plant Microbe Interact. 21, 919-930. doi: 10.1094/MPMI-21-7-0919

Vandenborre, G., Smagghe, G., and Van Damme, E. J. (2011). Plant lectins as defense proteins against phytophagous insects. Phytochemistry 72, 1538-1550. doi: 10.1016/j.phytochem.2011.02.024

Walling, L. L. (2000). The myriad plant responses to herbivores. J. Plant Growth Regul. 19, 195-216.

Walz, C., Juenger, M., Schad, M., and Kehr, J. (2002). Evidence for the presence and activity of a complete antioxidant defence system in mature sieve tubes. Plant J. 31, 189-197. doi: 10.1046/j.1365-313X.2002.01348.x

Wang, R., Shen, W., Liu, L., Jiang, L., Liu, Y., Su, N., et al. (2008). A novel lipoxygenase gene from developing rice seeds confers dual position specificity and responds to wounding and insect attack. Plant Mol. Biol. 66, 401-414. doi: 10.1007/s11103-007-9278-0

Wang, Y., Wang, X., Yuan, H., Chen, R., Zhu, L., He, R., et al. (2008). Responses of two contrasting genotypes of rice to brown planthopper. Mol. Plant Microbe Interact. 21, 122-132. doi: 10.1094/MPMI-21-1-0122

Wang, X. L., He, R. F., and He, G. C. (2005). Construction of suppression subtractive hybridization libraries and identification of brown planthopperinduced genes. J. Plant Physiol. 162, 1254-1262. doi: 10.1016/j.jplph.2005.01. 005

Wasternack, C. (2007). Jasmonates: an update on biosynthesis, signal transduction and action in plant stress response, growth and development. Ann. Bot. 100, 681-697. doi: 10.1093/aob/mcm079

Wei, Z., Hu, W., Lin, Q., Cheng, X., Tong, M., Zhu, L., et al. (2009). Understanding rice plant resistance to the Brown Planthopper (Nilaparvata lugens): a proteomic approach. Proteomics 9, 2798-2808. doi: 10.1002/pmic.200800840

Wielkopolan, B., and Obrêpalska-Stêplowska, A. (2016). Three-way interaction among plants, bacteria, and coleopteran insects. Planta 244, 313-332. doi: 10. 1007/s00425-016-2543-1

Wrzaczek, M., Brosché, M., Salojärvi, J., Kangasjärvi, S., Idänheimo, N., Mersmann, S., et al. (2010). Transcriptional regulation of the CRK/DUF26 group of receptor-like protein kinases by ozone and plant hormones in Arabidopsis. BMC Plant Biol. 10:95. doi: 10.1186/1471-2229-10-95

Yoshihara, T., Sogawa, K., Pathak, M. D., Juliano, B. O., and Sakamura, S. (1979). Soluble silicic acid as a sucking inhibitory substance in rice against the brown plant hopper (Delphacidae, Homoptera). Entomol. Exp. Appl. 26, 314-322. doi: 10.1111/j.1570-7458.1979.tb02932.x
Yoshihara, T., Sogawa, K., Pathak, M. D., Juliano, B. O., and Sakamura, S. (1980). Oxalic acid as a sucking inhibitor of the brown planthopper in rice (Delphacidae, Homoptera). Entomol. Exp. Appl. 27, 149-155. doi: 10.1111/j. 1570-7458.1980.tb02959.x

Yuan, H., Chen, X., Zhu, L., and He, G. (2005). Identification of genes responsive to brown planthopper Nilaparvata lugens Stål (Homoptera: Delphacidae) feeding in rice. Planta 221, 105-112. doi: 10.1007/s00425-004-1422-3

Zamioudis, C., and Pieterse, C. M. (2012). Modulation of host immunity by beneficial microbes. Mol. Plant Microbe Interact. 25, 139-150. doi: 10.1094/ MPMI-06-11-0179

Zarate, S. I., Kempema, L. A., and Walling, L. L. (2007). Silverleaf whitefly induces salicylic acid defenses and suppresses effectual jasmonic acid defenses. Plant Physiol. 143, 866-875. doi: 10.1104/pp.106.090035

Zhao, Y., Huang, F. K., Tong, X. L., Ling, B., and Pang, X. F. (2004). Secondary compounds in rice varieties resistant to Nilaparvata lugens. J. Appl. Ecol. 15, 2161-2164.

Zheng, S. J., van Dijk, J. P., Bruinsma, M., and Dicke, M. (2007). Sensitivity and speed of induced defense of cabbage (Brassica oleracea L.): dynamics of BoLOX expression patterns during insect and pathogen attack. Mol. Plant Microbe Interact. 20, 1332-1345. doi: 10.1094/MPMI-20-11-1332

Zheng, W., Ma, L., Zhao, J., Li, Z., Sun, F., and Lu, X. (2013). Comparative transcriptome analysis of two rice varieties in response to rice stripe virus and small brown planthoppers during early interaction. PLoS One 8:e82126. doi: 10.1371/journal.pone.0082126

Zhou, G., Qi, J., Ren, N., Cheng, J., Erb, M., Mao, B., et al. (2009). Silencing OsHI-LOX makes rice more susceptible to chewing herbivores, but enhances resistance to a phloem feeder. Plant J. 60, 638-648. doi: 10.1111/j.1365-313X. 2009.03988.x

Conflict of Interest Statement: The authors declare that the research was conducted in the absence of any commercial or financial relationships that could be construed as a potential conflict of interest.

Copyright (C) 2018 Rashid, Kim, Yeom, Yu, Manir, Moon, Kang and Chung. This is an open-access article distributed under the terms of the Creative Commons Attribution License (CC BY). The use, distribution or reproduction in other forums is permitted, provided the original author(s) and the copyright owner(s) are credited and that the original publication in this journal is cited, in accordance with accepted academic practice. No use, distribution or reproduction is permitted which does not comply with these terms. 